\title{
Climate in Africa sequentially shapes spring passage of Willow Warbler Phylloscopus trochilus across the Baltic coast
}

\author{
Magdalena Remisiewicz ${ }^{\text {Corresp., 1, } 2 \text {, Les G. Underhill }}{ }^{2,3}$ \\ 1 Bird Migration Research Station, Faculty of Biology, University of Gdańsk, Wita Stwosza 59, 80-308, Gdańsk, Poland \\ 2 Department of Biological Sciences, University of Cape Town, Cape Town, Rondebosch, 7701, South Africa \\ 3 Biodiversity and Development Institute, Unit 4, 25 Old Farm Road, Rondebosch, 7700, South Africa \\ Corresponding Author: Magdalena Remisiewicz \\ Email address: magdalena.remisiewicz@ug.edu.pl
}

Background. Many migrant birds have been returning to Europe earlier in spring since the 1980s. This has been attributed mostly to an earlier onset of spring in Europe, but we found the timing of Willow Warblers' passage to be influenced by climate indices for Africa as much as those for Europe. Willow Warblers' spring passage through northern Europe involves populations from different wintering quarters in Africa. We therefore expected that migration timing in the early, middle and late periods of spring would be influenced sequentially by climate indices operating in different parts of the winter range. Methods. Using data from daily mistnetting in 1 April-15 May over 1982-2017 at Bukowo (Poland, Baltic Sea coast), we derived an Annual Anomaly (AA, in days) of Willow Warbler spring migration. We decomposed this anomaly into three main periods (1-26 April, 27 April-5 May, 6-15 May); one-third of migrants in each period. We modelled three sequential time series of spring passage using calendar year and 15 large-scale climate indices averaged over the months of Willow Warblers' life stages in the year preceding spring migration as explanatory variables in multiple regression models. Nine climate variables were selected in the best models. We used these nine explanatory variables and calculated their partial correlations in models for nine overlapping sub-periods of AA. The pattern of relationships between AA in these nine sub-periods of spring and the nine climate variables indicated how spring passage had responded to the climate. We recommend this method for the study of birds' phenological responses to climate change. Results. The Southern Oscillation Index and Indian Ocean Dipole in Aug-Oct showed large partial correlations early in the passage, then faded in importance. For the Sahel Precipitation Index (PSAH) and Sahel Temperature Anomaly (TSAH) in Aug-Oct partial correlations occurred early then peaked in mid-passage; for PSAH (Nov-March) correlations peaked at the end of passage. NAO and local temperatures (April-May) showed low correlations till late April, which then increased. For the Scandinavian Index (Jun-Jul) partial correlations peaked in 
mid-passage. Year was not selected in any of the best models, indicating that the climate variables alone accounted for Willow Warblers' multiyear trend towards an earlier spring passage. Discussion. Climate indices for southern and eastern Africa dominated relationships in early spring, but western African indices dominated in mid- and late spring. We thus concluded that Willow Warblers wintering in southern and eastern Africa dominated early arrivals, but those from western Africa dominated later. We suggest that drivers of phenological shifts in avian migration are related to changes in climate at remote wintering grounds and at stopovers, operating with climate change in the north, especially for species with complex and long-distance migration patterns. 
1 Climate in Africa sequentially shapes spring passage of Willow Warbler Phylloscopus

2 trochilus across the Baltic coast

3

4 Magdalena Remisiewicz ${ }^{1,2}$, Les G. Underhill 2,3

5

$6{ }^{1}$ Bird Migration Research Station, Faculty of Biology, University of Gdańsk, Wita Stwosza 59,

7 80-308, Gdańsk, Poland; https://orcid.org/0000-0002-3613-5738;

8 Email address: magdalena.remisiewicz@ug.edu.pl

92 Department of Biological Sciences, University of Cape Town, Rondebosch, 7701, South

10 Africa; https://orcid.org/0000-0002-8758-1527

$11{ }^{3}$ Biodiversity and Development Institute, 25 Old Farm Road, Rondebosch, 7700, South Africa

12 Email address: les.underhill@uct.ac.za

13

14 Corresponding Author:

15 Magdalena Remisiewicz

16 Email address: magdalena.remisiewicz@ug.edu.pl 


\section{ABSTRACT}

Background. Many migrant birds have been returning to Europe earlier in spring since the 1980s. This has been attributed mostly to an earlier onset of spring in Europe, but we found the timing of Willow Warblers' passage to be influenced by climate indices for Africa as much as those for Europe. Willow Warblers' spring passage through northern Europe involves populations from different wintering quarters in Africa. We therefore expected that migration timing in the early, middle and late periods of spring would be influenced sequentially by climate indices operating in different parts of the winter range.

Methods. Using data from daily mistnetting in 1 April-15 May over 1982-2017 at Bukowo (Poland, Baltic Sea coast), we derived an Annual Anomaly (AA, in days) of Willow Warbler spring migration. We decomposed this anomaly into three main periods (1-26 April, 27 April-5 May, 6-15 May); one-third of migrants in each period. We modelled three sequential time series of spring passage using calendar year and 15 large-scale climate indices averaged over the months of Willow Warblers' life stages in the year preceding spring migration as explanatory variables in multiple regression models. Nine climate variables were selected in the best models. We used these nine explanatory variables and calculated their partial correlations in models for nine overlapping sub-periods of AA. The pattern of relationships between AA in these nine subperiods of spring and the nine climate variables indicated how spring passage had responded to the climate. We recommend this method for the study of birds' phenological responses to climate change.

Results. The Southern Oscillation Index and Indian Ocean Dipole in Aug-Oct showed large partial correlations early in the passage, then faded in importance. For the Sahel Precipitation Index (PSAH) and Sahel Temperature Anomaly (TSAH) in Aug-Oct partial correlations occurred early then peaked in mid-passage; for PSAH (Nov-March) correlations peaked at the end of passage. NAO and local temperatures (April-May) showed low correlations till late April, which then increased. For the Scandinavian Index (Jun-Jul) partial correlations peaked in midpassage. Year was not selected in any of the best models, indicating that the climate variables alone accounted for Willow Warblers' multiyear trend towards an earlier spring passage.

Discussion. Climate indices for southern and eastern Africa dominated relationships in early spring, but western African indices dominated in mid- and late spring. We thus concluded that Willow Warblers wintering in southern and eastern Africa dominated early arrivals, but those 
49 from western Africa dominated later. We suggest that drivers of phenological shifts in avian 50 migration are related to changes in climate at remote wintering grounds and at stopovers, 51 operating with climate change in the north, especially for species with complex and long52 distance migration patterns.

53 Subjects Animal Behaviour, Ecology, Zoology, Climate Change Biology

54 Keywords sequential migration, climate change, spring phenology, migration timing, Annual 55 Anomaly, Phylloscopus trochilus, large-scale climate indices, SOI, IOD, NAO 


\section{INTRODUCTION}

58 Many migrant birds have been arriving earlier for the European spring since about the 1980s; this has been attributed to climate change and gradually increasing springtime temperatures in Europe (e.g. Sokolov et al., 1998; Hüppop \& Hüppop, 2003; Vähätalo et al., 2004; Tøttrup, Thorup \& Rahbek, 2006; Miles et al., 2017; Lehikoinen et al., 2019). But many long-distance Palaearctic migrants use wintering grounds that span Africa, for example Barn Swallow Hirundo rustica, European Reed Warbler Acrocephalus scirpaceus, Sedge Warbler A. schoenobaenus, Red-backed Shrike Lanius collurio, Spotted Flycatcher Muscicapa striata, Garden Warbler Sylvia borin and Willow Warbler Phylloscopus trochilus (Cepák et al., 2008; Fransson \& HallKarlsson, 2008; Bairlein et al., 2014; Valkama et al., 2014). Migration is initiated thousands of kilometres from the breeding grounds and weeks before the birds arrive in Europe, so changing conditions in the wintering areas should also affect the timing of these long-distance migrants' passage (Cotton 2003; Gordo 2007). The migrants' responses to climate change at their northern European breeding grounds might result from a combination of different populations' responses to conditions they had encountered at their respective winter quarters. Identifying the pattern of these relationships at multiple locations across widespread wintering areas is key to understanding a species' response to climate change at its breeding grounds, because of carryover effects of shifts in one life stage on phenology of the next stages in migrants (e.g. Barshep et al., 2011; Tobolka et al., 2018; Tomotani et al., 2018).

Most studies have attributed the trends in the recent timing of the migrants' arrival in Europe and North America to the increase in spring temperatures at their northern stopovers and breeding grounds (e.g. Sokolov et al., 1998; Cotton, 2003; Hüppop \& Hüppop, 2003; MillerRushing et al., 2008; Wood \& Kellermann, 2015; Miles et al., 2017; Usui, Butchart \& Phillimore, 2017; Zaifman et al., 2017; Lehikoinen et al., 2019; Redlisiak, Remisiewicz \& Mazur, 2021). Conditions at the breeding grounds have been reported to drive phenological changes in the breeding of long-distance migrants more than conditions at the non-breeding grounds (e.g. Ockendon, Leech \& Pearce-Higgins, 2013). Yet conditions in the non-breeding season influence the migrants directly or indirectly, including carryover effects on spring migration by influencing overwinter survival and the: 1) timing of departure from the wintering grounds, 2) birds' condition on departure, 3) duration and frequency of stopovers, 4) size of populations arriving from the wintering grounds (overviews in Gordo, 2007 and Remisiewicz \& 
88 Underhill, 2020). A few studies have related migrants' spring arrivals in Europe to conditions at 89 non-breeding areas, including temperature and rainfall at migration stopovers (e.g. Gordo, 2007; Saino et al., 2007; Saino \& Ambrosini, 2008; Tøttrup et al., 2012; Halupka et al., 2017; Haest, Hüppop \& Bairlein, 2020) and at the wintering grounds (e.g. Katti \& Price, 1999; Cotton, 2003; Salewski et al., 2004; González-Prieto \& Hobson, 2013; Ouwehand \& Both, 2017; Redlisiak, Remisiewicz \& Nowakowski, 2018; Tobolka et al., 2018; Remisiewicz et al., 2019; Haest, Hüppop \& Bairlein, 2020; Tomotani et al., 2021). Most studies on long-distance migrants, however, have focused on relationships between their spring arrival in Europe and conditions at their wintering grounds and stopovers in western Africa and southwestern Europe, reflected by the Sahel Precipitation Index (e.g. Zwarts et al., 2009, Tobolka et al., 2018), precipitation and temperatures in the Sahel and in Europe (e.g. Saino et al., 2007; Gordo \& Sanz, 2008; Tøttrup et al., 2010; Haest, Hüppop \& Bairlein 2020), the Northern Atlantic Oscillation Index (NAO) in winter (e.g. Forchhammer, Post \& Stenseth, 2002; Cotton, 2003; Ahola et al., 2004; Gordo, Barriocanal \& Robson, 2011; Haest, Hüppop \& Bairlein, 2018), and the Normalized Difference Vegetation Index (NDVI) (e.g. Balbontín et al., 2009; Tøttrup et al., 2010; Jørgensen et al., 2016; Thorup et al., 2017, Tomotani et al., 2021). Fewer studies have shown that the spring arrival of these migrants in Europe is also related to conditions in eastern and southern Africa, reflected by temperature (e.g. Cotton, 2003); NDVI (e.g. Tøttrup et al., 2012), the Southern Oscillation Index (SOI/ENSO) (e.g. Stenseth et al., 2003; Cotton, 2003), and the Indian Ocean Dipole (IOD) (e.g. Hušek et al., 2008; Tryjanowski, Stenseth \& Matysioková, 2013; Tobolka et al., 2018). Most studies showing how climate at the non-breeding grounds influences the spring arrival of migrants have focused on locations in western Europe, where most migrants arrive from western Africa (Cepák et al., 2008; Fransson \& Hall-Karlsson, 2008; Zwarts et al., 2009; Bairlein et al., 2014; Valkama et al., 2014). Few studies have shown the effects of climate change using indices of climatic or vegetation variation from both hemispheres (Cotton, 2003; Altwegg et al., 2012; Ockendon, Leech \& Pearce-Higgins, 2013; Bussière, Underhill \& Altwegg, 2015; Chambers et al., 2017; Tomotani et al., 2021). Even fewer authors have demonstrated the combined influences of some climate indices and temperatures in different parts of Africa on the arrival of species breeding in Europe (Cotton, 2003; Tobolka et al., 2018). In contrast to those studies, in an earlier study we showed that the timing of Willow Warblers' arrival in northern Europe in spring is explained by a combination of at least seven climate indices that operate in different parts of 
119 Africa and in Europe (Remisiewicz \& Underhill, 2020). We thus suggest that the spectrum of

120 climate factors shaping spring arrivals in Europe for species with winter ranges that span most of

121 Africa has been largely under-represented. In this study we therefore set out to examine in more

122 detail the combined effects of a wide range of climate factors that affect Willow Warblers annual 123 cycle.

124 The species winters throughout Africa south of the Sahara Desert and two subspecies 125 migrate across the Polish coast of the Baltic Sea past the bird ringing station at Bukowo, Poland $126\left(54^{\circ} 20^{\prime}-54^{\circ} 27^{\prime} \mathrm{N}, 16^{\circ} 14^{\prime}-16^{\circ} 24^{\prime} \mathrm{E}\right)$, so we chose Willow Warblers as a representative long127 distance migrant to determine how widespread patterns of climate might influence the timing of 128 migration in complex ways. The two subspecies tend to occupy different winter quarters in 129 Africa, but both breed in northern Europe (Bensch, Bengtsson \& Åkesson, 2006; Bensch et al., 130 2009; Zhao et al., 2020); thus we expected that the pattern of their spring arrivals at stopovers on 131 the Baltic Sea coast might be related to climate factors operating in different areas in Africa. Ph. t. trochilus arrives at its breeding grounds in central Sweden from winter quarters in west Africa before Ph. t. acredula from eastern and southern Africa (Hedenström \& Pettersson, 1984). These subspecies' migration routes overlap at Bukowo (Remisiewicz \& Underhill; 2020), which is ca $600 \mathrm{~km}$ south of their hybridisation zone in central Sweden (Bensch, Bengtsson \& Åkesson, 2006; Bensch et al., 2009). We expected that the species's spring passage through Bukowo would be a continuously changing mixture of populations from different wintering quarters in Africa, possibly in a consistent pattern. Thus we investigated whether the timing of the early, middle and late cohorts of Willow Warblers at Bukowo during spring passage could be related to climate indices operating in different parts of their winter range. We also examined whether the timing of the spring passage at Bukowo was related to the numbers of juvenile Willow Warblers that had migrated through the site the previous autumn, using these numbers as a proxy for breeding success. Additionally, we aimed to test if a temporal decomposition of the Annual Anomaly (AA) of migration that we had developed (Remisiewicz \& Underhill; 2020)

145 helped to identify any temporal patterns in the relationships between consecutive periods of the 146 AA and different climate indices.

\section{MATERIALS \& METHODS}


150 Two subspecies of Willow Warbler, Ph. t. trochilus and Ph. t. acredula, migrate through the

151 region around the Baltic Sea to breeding grounds in northwestern Europe (Remisiewicz \&

152 Underhill, 2020), where they meet at a migratory divide (Fig. 1) (Tomiałojć \& Stawarczyk,

153 2003; Bensch, Bengtsson \& Åkesson, 2006; Bensch et al., 2009). In spring Ph. t. trochilus

154 migrates ca $5000 \mathrm{~km}$ from winter quarters mainly in west and central Africa south of the Sahara

155 to breeding grounds in southern Scandinavia, Poland, and western and southern Europe; Ph. $t$.

156 acredula flies 5000-12000 km from wintering grounds mainly in central, eastern and southern

157 Africa to breeding grounds in northern Sweden, Finland, eastern Poland and far northeastern

158 Europe (Fig. 1) (Hedenström \& Pettersson, 1987; Cramp \& Brooks, 1992; Bensch, Andersson \&

159 Akesson, 1999; Tomiałojć \& Stawarczyk, 2003; Bensch, Bengtsson \& Åkesson, 2006; Fransson

160 \& Hall-Karlsson, 2008; Bensch et al., 2009; Zwarts et al., 2009; Valkama et al., 2014; Lerche-

161 Jørgensen et al., 2017; Maciąg et al., 2017; Zhao et al., 2020). The proportion of Willow

162 Warblers that winter in eastern and southern Africa increases along a west-east axis across the

163 breeding grounds (Zwarts et al., 2009). Ph. t. trochilus arrives in the region of the migratory

164 divide at $60^{\circ} 00^{\prime}-63^{\circ} 00^{\prime} \mathrm{N}$ in central Sweden (Fig. 1) in April, about two weeks earlier than $P h$.

165 t. acredula (Hedenström \& Pettersson, 1984). The sequence and proportions of each subspecies

166 that migrate through Bukowo are difficult to estimate because the subspecies differ only subtly in

167 colour and size (Bensch et al., 2009). These slight differences are further confounded by size

168 differences between the sexes (Svensson, 1992).

169 Willow Warblers arrive in northwestern Europe in April-May, breed in June-July,

170 migrate south in August-October, then stay in Africa in November-March (Cramp \& Brooks,

171 1992; Herremans, 1999; Tomiałojć \& Stawarczyk, 2003; Dean, 2005; Zwarts et al., 2009; Kluen,

172 Nousiainen \& Lehikoinen, 2017). So we considered April-May to be "spring migration",

173 August-October to be "autumn migration" and "winter" to be November-March.

174

175 Study site and sampling

176 We used daily numbers of Willow Warblers ringed during spring migration (1 April-15 May) in

177 1982-2017 using standardised protocols at the Bukowo ringing station on the Baltic Sea coast

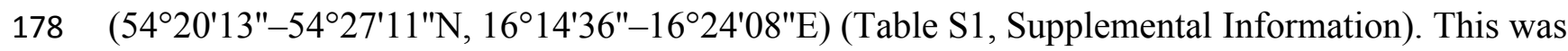

179 the same dataset (Supplement 2) as used in our previous paper (Remisiewicz \& Underhill, 2020),

180 but here we analysed the data in greater detail and processed it differently to determine any

Peer) reviewing PDF | (2020:12:56300:3:1:NEW 24 Jan 2022) 
181 changes in the influence of each climate index over spring passage. We also used the total

182 numbers of juvenile Willow Warblers caught at Bukowo each autumn migration (14 August-29

183 October) in 1981-2016. Migrating passerines were caught in mist nets placed in mixed coastal

184 and riparian forests and bushes on spits between the Baltic Sea and the neighbouring Bukowo

185 and Kopań coastal lakes (Busse \& Meissner, 2015; Nowakowski et al., 2021). In 1982-2010

186 ringing was conducted on the spit of Lake Kopań $\left(54^{\circ} 27^{\prime} 11^{\prime \prime} \mathrm{N}, 16^{\circ} 24^{\prime} 08^{\prime \prime} \mathrm{E}\right)$, but then holiday

187 housing was developed nearby and human disturbance increased. So in 2012-2017 ringing

188 operations were moved $16 \mathrm{~km}$ east to the quiet spit of Lake Bukowo (54²0'13"N, 16 $\left.14^{\circ} 36^{\prime \prime} \mathrm{E}\right)$.

189 Both locations occupy similar coastal habitats on narrow spits of coastal lakes that channel

190 migrating birds' passage, so we combined the results from both sites into one dataset

191 ("Bukowo"). The number of 8 m-long nets was stable within each season, but ranged from 35 to

19257 in spring, and from 38 to 76 in autumn in different years (Table S1). Ringing was conducted

193 each year from 23 March-15 May and from 12 August-1 November. This extended beyond the

194 Willow Warblers' passage in spring (1 April-15 May) and in autumn (14 August-29 October).

195 In several springs ringing was prolonged beyond the standard period and mostly local Willow

196 Warblers were caught after 15 May, as indicated by local recaptures (Supplement 2). Birds

197 caught in some autumns before 14 August were also mostly local breeders (Supplement 2). Birds

198 were caught between dawn and dusk, ringed, measured, aged, and then released (Busse \&

199 Meissner, 2015). In spring all Willow Warblers were in the same plumage and were aged as "full

200 grown"; in autumn they were aged as juveniles or adults (Svensson, 1992; Demongin, 2016). We

201 counted an individual only at the first capture in each season. The fieldwork was conducted with

202 the annual approval of the General Directorate for Environmental Protection, Poland, supported

203 by the Polish Academy of Sciences (last decision: DZP-WG.6401.03.97.2017.jro), and the

204 Marine Office, Słupsk (last decision: OW-A-510/87/17/ds).

205

206

Climate indices

207 We used 15 large-scale and local climate indices for the Willow Warbler wintering grounds in 208 western, eastern and southern Africa and for their migration routes through Europe (Fig. 1, Table

209 1). The large-scale climate indices reflect rainfall and temperatures over wide areas (Wang \&

210 Schimel, 2003; Fig. 1). For the Sahel region, where no large-scale climate index was available,

211 we used the Sahel Precipitation Index (PSAH) and the Sahel temperature anomaly (TSAH) 


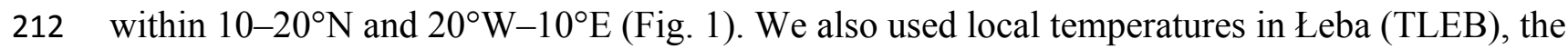

213 closest coastal weather station to Bukowo. We downloaded monthly values for these climate

214 indices from the websites of weather services and visualised their influence based on these

215 sources and the literature (Table 1). Negative summer values of the Scandinavian index

216 (SCAND) are related to high rainfall and low temperatures over Scandinavia (Bueh \&

217 Nakamura, 2007). The positive phase of the North Atlantic Oscillation Index (NAO) in winter is

218 related to warm and wet winters in western Africa and early springs in western Europe (Hurrell,

219 1995). The positive winter Indian Ocean Dipole (IOD) is related to high rainfall in eastern and

220 southeastern Africa (Marchant et al., 2006), and usually varies independently of the Southern

221 Oscillation Index (SOI) (Ashok, Guan \& Yamagata, 2003). A negative winter SOI indicates El

222 Niño conditions, related to dry and hot weather across southern Africa but warm and wet weather

223 in eastern Africa; a positive winter SOI indicates La Niña conditions, which has the opposite

224 effect of an El Niño on climate in southern and eastern Africa, with a weak relation to cool

225 conditions in western Africa south of the Sahel (Richard et al., 2001; McPhaden, Santoso \& Cai,

226 2020). The monthly Sahel Precipitation Index (PSAH) and the Sahel Temperature Anomaly

227 (TSAH) reflect the anomalies of these climate features within the western Sahel where Willow

228 Warblers overwinter (Fig. 1, Table 1). Negative monthly values of PSAH indicate low

229 precipitation in relation to the 1980-2009 baseline. Negative monthly values of TSAH indicate

230 high temperature in relation to the 1982-2017 baseline. These indices were used as proxies for

231 the conditions that the Willow Warblers experience during consecutive periods of their life (Fig.

232 1). Thus we averaged each climate index, including PSAH, TSAH and TLEB, for April-May

233 (spring migration), November-March (wintering), August-October of the previous year (autumn

234 migration), and June-July the previous year (breeding). For further analyses we selected the

235 climate indices in the regions where Willow Warblers occur, in the months we examined, as in

236 our previous study (Remisiewicz \& Underhill, 2020). For each climate index we used only the

237 periods when Willow Warblers occur within the area influenced by that index in the year before

238 their spring migration (Fig. 1). For example, we used the indices of climate such as PSAH,

239 TSAH, IOD and SOI that cover Willow Warblers' non-breeding grounds for August-October

240 and November-March, the periods when we expected the birds to occur in Africa where these

241 indices operate, but not for April-May and June-July, when the birds should be on spring

242 passage or at the breeding grounds in Europe. By these criteria we selected 15 climate variables

Peer] reviewing PDF | (2020:12:56300:3:1:NEW 24 Jan 2022) 
243 for further analysis (Table 1). We used these 15 indices and the year (Table 1) as explanatory

244 variables in multiple regression models to identify their combined effects on the yearly timing of

245 Willow Warbler spring migration across the southern Baltic Sea coast. We avoided using

246 correlated climate variables and we monitored Variance Inflation Factors (VIF) in our multiple

247 regression models (Dormann et al., 2013) to mitigate any influence of multicollinearity on our

248 results, as in Remisiewicz \& Underhill (2020).

249

250 Statistical analyses

251 Selection of data on spring and autumn migration at Bukowo

252 We analysed the numbers of Willow Warblers caught each day between 1 April and 15 May at

253 Bukowo in 1982-2017, but excluded 1993 and 2011, years when fewer than 30 Willow Warbler

254 were caught. Our dataset thus included 34 spring seasons with more than 30 individuals captured

255 (Table S1). These daily totals were transformed to daily proportions (percentages) of the total

256 number of this species caught that spring. The percentages were summed to produce a

257 cumulative arrival curve for the season so that each year had an equal weight in generating the

258 multiyear arrival curve. We also used the total numbers of juvenile Willow Warblers caught at

259 Bukowo in the previous autumn migration (14 August-29 October) in 1981-2016 as a measure

260 of the species' breeding success north and northeast of Bukowo. To account for any differences

261 in catching effort between autumns, we calculated the number of juveniles caught each autumn

262 per 50 mist nests, by dividing the total of juveniles caught each autumn by the number of mist

263 nets used that season, and multiplying this index by 50 (Table S1). The numbers of Willow

264 Warblers did not differ between the Kopań and Bukowo ringing sites, either in each season's

265 totals or in the numbers of birds caught per mistnet, in spring and in autumn (Table S3); thus we

266 combined the data from these locations in one multiyear dataset.

267

268 Methods of calculating the Annual Anomaly and its temporal decomposition

269 We calculated the time series of the annual anomaly (AA) for the whole spring in relation to the

270 average cumulative curve of spring passage in 1982-2017 (Fig. 2), as in Remisiewicz \&

271 Underhill (2020). Then we selected the dates of the thirds of passage $(0-33 \%, 34-66 \%$ and $67-$

$272100 \%$ of Willow Warblers caught; Table 2) of the average spring migration derived from the

273 overall multiyear cumulative curve (Fig. 2). We used these dates to decompose the annual

Peer] reviewing PDF | (2020:12:56300:3:1:NEW 24 Jan 2022) 
274 anomaly each spring into three non-overlapping main periods (Fig. 2, Table 2). The three time

275 series formed in this way reflect the year-to-year changes in passage within each of the three

276 main periods of the spring seasons over the years we studied. First, we used these three time

277 series as explanatory variables, along with the year and the number of birds caught each spring,

278 in multiple regression to test for any potential effect of bird numbers on the arrival dates

279 (Tryjanowski \& Sparks 2001). Then we checked for any trends over 1982-2017 in these three

280 time series using linear regression, applying the Benjamini-Hochberg correction for multiple

281 comparisons (Benjamini \& Hochberg, 1995).

282

283 Multiple regression models for periods of AA

284 As in our previous study (Remisiewicz \& Underhill, 2020), we standardized response and

285 explanatory variables so that they had a mean of 0 and a standard deviation of 1 . This scaling

286 does not influence the statistical significance of the results but does aid interpretation. We

287 modelled each of the three main periods as a response variable and used the 15 large-scale

288 climate indices and the year as 16 explanatory variables (Table 1) in multiple regression models

289 using the R package "MuMIn 1.43.6” (Bartoń, 2019), as we did with overall AA in the previous

290 study (Remisiewicz \& Underhill, 2020). We retained year as an explanatory variable to control

291 for its effect while modelling the effects of the climate variables (Frost, 2019); if it was not

292 significant in the models that were finally selected, we could infer that the long-term trend had

293 been subsumed into the climate variables. We used the explanatory variables as linear functions

294 of AA because they showed stronger linear relationships with the overall AA than when used as

295 polynomial terms (Remisiewicz \& Underhill, 2020). We used "all subsets regression" and

296 calculated the Akaike Information Criteria corrected for small sample size (AICc) for each

297 subset of the explanatory variables, then we selected the best model using model ranking by

298 AICc with the package "MuMIn 1.43.6" (Bartoń, 2019). The adjusted coefficient of

299 determination $\left(\mathrm{Adj}^{2}\right)$ measured the proportion of variation explained by the best models for

300 each of the spring periods. We calculated partial correlation coefficients $(p R)$ for each best model

301 using the package "ppcor 1.1" (Kim, 2015). The $p R$ reflects the direction and the strength of the

302 correlation between the response variable and each explanatory variable while removing the

303 effects of the remaining variables. The statistical analyses were conducted in R 4.0.3 (R Core

304 Team, 2020). 
Motivated by our results, we applied the same approach to a series of nine overlapping

306

307

308

309

310

311

312

313

314

315

316

317

318

319

320

321

322

323

324

325

326

327

328

329

330

331

332

333

334

335 sub-periods of the AA (Table 2). Each sub-period spanned $20 \%$ of the the multiyear curve ( 0 $20 \%, 10-30 \%, \ldots, 80-100 \%$; Table 2 ), and we used the dates for these ranges from the multiyear cumulative curve to divide the AA for each spring into the nine sub-periods, in the same way we initially split the passage period in thirds (Fig. 2). In the Results, we show that nine of the 15 candidate climate indices were selected in one or more of the three best-fitting models for the three main periods of the AA and contributed most in the top models $\left(\Delta \mathrm{AIC}_{\mathrm{c}}<2\right)$. We investigated the influence of these nine explanatory variables throughout the spring migration over the nine sub-periods. We then produced a graphical display that indicated the importance of each explanatory variable as it waxed or waned through spring passage by plotting the sequential partial correlation coefficients $p R$ for the nine explanatory variables. The nine sub-periods overlapped, so these results cannot be interpreted as a series of formal statistical models. The plots are intended to be interpreted as visual and diagnostic displays, in the spirit of the exploratory approach to data analysis pioneered by Tukey (1980). It is helpful to think of this approach as an extension of the concept of the moving average, a similar "windowing" approach used in descriptive time series analysis to visualize patterns through time.

Analysing relationships between spring migration and the number of juveniles caught the previous autumn at Bukowo

To explore any potential effect of seasonal breeding success on the Willow Warblers' migration timing the following spring, we used linear regression to model the relationship between the overall Annual Anomaly and its three main periods at Bukowo each year in 1982-2017 and the count of juveniles captured at the site in the previous autumn over 1981-2016 (Njuv_1y). The number of juveniles caught in autumn 1982 was nearly five times larger than the mean numbers caught in other autumns though the numbers and locations of mist nets were similar each year (Table S1). This exceptional number possibly arose from an unusual weather pattern that season, which might have changed the species' migration corridor across the Baltic, so we excluded this season from our analysis. Thus we used 33 years of data for this analysis, a different dataset from that used for spring. In the preliminary multiple regressions that included the count of juveniles this explanatory variable was never selected in any of the top models $\left(\Delta \mathrm{AIC}_{\mathrm{c}}<2\right)$, likely because its effect was weaker than the effects of the climate variables. We therefore did not include the 
336

337

338

339

340

341

342

343

344

345

346

347

348

349

350

351

352

353

354

355

356

357

358

359

360

361

362

363

364

365

366

count of juveniles in our final multiple regression models but analysed this relationship separately. The distribution of the count of juveniles departed from normal, so we applied a square root transformation to standardise this data and used the output as the explanatory variable in regression analyses.

\section{RESULTS}

Differences in the long-term trends of Willow Warbler migration timing in three main nonoverlapping periods of spring

Based on the mean overall cumulative curve of the numbers of Willow Warblers caught in spring over 1982-2017, the 0-33\% range of passage spanned 1-26 April, 34-66\% spanned 27 April-5 May, and 67-100\% spanned 6-15 May (Fig. 2A). So we divided AA into three main periods in each year using these dates (Fig. 2B, Table 2). The numbers of birds caught each spring had no significant influence on anomalies in these three periods and on the overall AA (Table S3). Next we analysed the trends of these time series against the year (Fig. 3). The passage of Willow Warblers within the first main period shifted earlier by 2.4 days on average over 1982-2017 (Fig. 3A). The passage in the second period shifted earlier by 2.3 days on average over those years (Fig. 3B). These shifts jointly contributed to $87 \%$ of the shift in the overall anomaly of spring passage over the 36 years of our study (Fig. 3, Table S7). The shift of 0.7 days earlier on average for the last period of spring was not significant (Fig. 3C). The overall timing of Willow

Warbler spring migration at Bukowo over 1982-2017, reflected by the overall Annual Anomaly, advanced on average by 5.4 days, a sum of the shifts in all three main periods (Fig. 3D; Remisiewicz \& Underhill, 2020). The linear regression, although significant, explained only $20 \%$ and $21 \%$ of the variation in the first two main periods of spring (Fig. 3A, 3B, Table S7), so we then examined other sources of year-to-year variation besides these multiyear trends.

\section{The relationships between large-scale climate indices and Willow Warbler migration in}

\section{three main periods of spring}

In our earlier study (Remisiewicz \& Underhill, 2020) we identified a set of climate variables that explained year-to-year variation in the overall Annual Anomaly (AA) of Willow Warbler spring migration at Bukowo in 1982-2017; here we explore the influences of these climate variables on the timing of the species' spring migration at a finer resolution by examining the three main 
367 periods of spring. The anomaly of passage in the first period (MP1) was significantly negatively 368 related to six climate variables selected by the best model, which explained $\mathrm{Adj}^{2}=56.6 \%$ of its

369

370

371

372

373

374

375

376

377

378

379

380

381

382

383

384

385

386

387

388

389

390

391

392

393

394

395

396

397

variation (Table 3; full model in Table S8, model selection in Table S9, model diagnostics in Fig. $\mathrm{S} 2$ ). The best model for the middle period (MP2) explained $\mathrm{Adj}^{2}=66.4 \%$ of its variation by a negative relationship to each of five climate variables (Table 3, Table S10, Fig. S3). The anomaly of the last period (MP3) was negatively related to each of five climate indices, as indicated by the best model, which explained $30.7 \%$ of its variation (Table 3, Table S11, Fig. S4). All these relationships were negative (Table 3), meaning an earlier passage with a higher climate index and vice versa. Nine climate variables, which were selected in the best models for at least one of the three main periods (Table S5) and contributed at least $60 \%$ in any of the three sets of top models with $\triangle \mathrm{AICc}<2$ (Table $\mathrm{S} 13$ ), were used for the multiple regressions of the nine sub-periods of spring. For pairs of highly correlated climate variables, for example SOI (Aug-Oct_1y) and (Nov-Mar) (Table S5), we chose the variable that contributed most to the top models (Table S13), to avoid multicollinearity.

SOI and IOD significantly influenced the timing of migration in the first period of spring, but had no influence on passage in the last period (Table 3). PSAH (Aug-Oct_1y) influenced migration in the first two periods; TSAH affected the first period, but had no influence on the last period; PSAH (Nov-Mar) influenced the passage in the last period. SCAND (Jun-Jul_1y) influenced migration in all three main periods of spring.

For the overall AA, the best model explained $59.4 \%$ of the variation and selected seven climate variables, six of which were among the indices selected in the best models for the three periods of AA (Table S5, Table S12, Table S13, Fig. S5). The effect of TSAH (Nov-Mar) on AA corresponded with the effect of TSAH (Aug-Oct_1y) on MP1 (Table 3). For all four best models, an inspection of the residuals (Figs S2-S5) showed they met the assumptions of multiple linear regression (Crawley, 2013). All values of VIF < 10 (Table 3) indicated no harmful collinearity in any of these models (Dormann et al., 2013).

\section{Sequence of relationships between large-scale climate indices and the timing of migration in nine overlapping sub-periods of spring}

The regression models for each of the nine overlapping AA sub-periods against the nine selected explanatory variables suggested a gradual change in the influence of each climate index on the

Peer] reviewing PDF | (2020:12:56300:3:1:NEW 24 Jan 2022) 
398 timing of Willow Warbler passage in subsequent periods of spring (Fig. 4A-I, Table S14, Table 399 S15). The graphical display (Fig. 4A-I) should be interpreted in conjunction with the formal

400

401

402

403

404

405

406

407

408

409

410

411

412

413

414

415

416

417

418

419

420

421

422

423

424

425

426

427

428

models (Table 3, Table S14). Most of these relationships were negative (Table S14), indicating an earlier passage with higher values of the climate index, as for the three main periods (Table $3)$.

For the Southern Oscillation Index (SOI) and the Indian Ocean Dipole (IOD) in Aug-Oct of the previous year we found large correlations with the early and middle part of spring passage, which decreased in importance after mid-passage (Fig. 4A-B). The Sahel Temperature Anomaly (TSAH) in these months showed smaller partial correlations with the passage in the first half of spring, peaked in about mid-passage, before fading in importance (Fig. 4C). Similarly, the correlations for the Sahel Precipitation Index (PSAH) in Aug-Oct were moderate at the beginning of spring, peaked in mid-passage and then faded (Fig. 4D). PSAH in Nov-March showed low partial correlations in the first and the second periods of spring, but increased in the last part of spring migration (Fig. 4E). NAO in Nov-March showed low but consistent correlations over the whole passage (Fig. 4F). Partial correlations for NAO in Apr-May were moderate at the beginning of spring passage, peaked in the middle, then decreased at the end (Fig. 4G). The correlations for the local April-May mean temperatures in Łeba (TLEB AprMay) were small at the beginning of spring, increased towards mid-passage, then decreased towards the end of migration (Fig. 4H). SCAND in Jun-Jul of the previous year showed moderate partial correlations for the first third of spring, peaked in mid-passage and remained important until the seasons' end (Fig. 4I).

\section{Relationship between number of juveniles caught the previous autumn and the timing of spring migration}

The SCAND index in June-July of the previous year, which reflects conditions in the previous breeding season in Scandinavia (Fig. 1), was related to the timing of Willow Warbler migration the following spring (Table 3, Fig. 4I, Table S14). We expected that a warm summer in Scandinavia might enhance breeding success, which should produce more juveniles migrating south in autumn, which in turn would likely influence the passage north the following spring. Thus we evaluated if the numbers of juvenile Willow Warblers migrating through Bukowo in autumn were related to the species' migration timing in the following spring. So we checked if 
429 AA in each of the three main periods of spring was related to the number of juveniles caught the 430 previous autumn. The numbers of juveniles caught in autumn thus served as a proxy for the

431

432

433

434

435

436

437

438

439

440

441

442

443

444

445

446

447

448

449

450

451

452

453

454

455

456

457

458

459

Willow Warblers' breeding success north and northeast of Bukowo (Fig. 1).

The number of juveniles in autumn, as the sole explanatory variable, accounted for $21 \%$ and $31 \%$ of the variation in the timing of the first and the middle main periods of spring passage (Fig. 5A-B). This relationship was not significant in the last third of spring (Fig. 5C), but did explain $29 \%$ of the variation in the overall passage (Fig. 5D). Migration through Bukowo, especially in the first and the middle periods of spring, occurred later the larger the numbers of juveniles caught in the previous autumn migration and vice versa (Fig. 5, Table S16). The number of juveniles in autumn at Bukowo was not correlated with the SCAND index in Jun-July of the same year (Pearson's correlation: $r=-0.08, p=0.65$ ).

\section{DISCUSSION}

Indices of climate in southern and eastern Africa (IOD and SOI) were related to the timing of Willow Warbler's arrival at Bukowo in the early and middle of the three main periods of spring passage. The indices of climate in western Africa (TSAH, PSAH and NAO), showed weaker relationships to the first period, which increased in the middle and late periods. This pattern leads us to suggest that Willow Warblers from eastern and southern Africa arrive early at the southern coast of the Baltic Sea, where they mix with populations from western Africa, which mostly arrive later in the season. This sequence is the inverse of the arrival timing of the two subspecies of Willow Warblers at their breeding grounds in Sweden (Hedenström \& Pettersson, 1984; Bensch, Bengtsson \& Åkesson, 2006; Bensch et al., 2009), so we present possible explanations for this apparent discrepancy. We found that climate indices reflecting conditions at the wintering grounds and at stopover sites in Africa influenced migration timing at Bukowo more than local spring temperatures, which contradicted the findings of other studies (e.g. Usui, Butchart \& Phillimore, 2017; Lehikoinen et al., 2019). We explain how a combination of remote and local climate variables has enabled the pattern of earlier arrivals in spring and the earlier breeding in Europe that has been observed for many migrant birds since the 1980s. We found the long-term trend for Willow Warblers to arrive earlier in spring at Bukowo, as at many other locations in Europe (Remisiewicz \& Underhill, 2020), was caused by an earlier passage in the first two main periods of spring, but not in the last period; we will discuss this novel insight.

PeerJ reviewing PDF | (2020:12:56300:3:1:NEW 24 Jan 2022) 
Long-term trends in the timing of Willow Warbler passage in three main sub-periods of spring

\section{3}

464

465

466

467

468

469

470

471

472

473

474

475

476

477

478

479

480

481

482

483

484

485

486

487

488

489

490

The spring migration of Willow Warblers at Bukowo over the 36 years of our study shifted earlier in the first two main periods of the season (1 April-5 May), but not in the third period (615 May). These combined changes led to a shift in the Annual Anomaly for the whole spring (Fig. 3). Willow Warblers migrate through Bukowo to breeding grounds in Sweden, where the population size decreased over 1975-2016 (Green et al., 2017), to Finland where the population increased in this period (Finnish Natural History Museum, 2017), and to other breeding grounds (Fig. 1). Birds from these breeding populations mix at Bukowo in unknown proportions, thus it was difficult to relate the numbers of birds caught at this station to population trends. The earlier arrival of Willow Warblers at Bukowo over the years we examined (Fig. 3) should be considered an indication of the extent of this phenomenon, rather than an absolute measure of the shift to an earlier spring passage. These shifts correspond with the advance in Willow Warbler arrivals observed over other years at other locations in Europe (e.g. Sokolov et al., 1998; Cotton, 2003; Hüppop \& Hüppop, 2003; Tøttrup, Thorup \& Rahbek, 2006; Hedlund et al., 2015; Miles et al., 2017; Remisiewicz \& Underhill, 2020). Other studies of long-distance migrants have shown larger shifts in the timing of early percentiles of the spring passage $(5 \%, 10 \%)$ than for late percentiles $(90 \%, 95 \%)$, as in our results. The earlier studies explained the pattern by showing a stronger effect on the beginning of migration than on its end of increased temperatures or other climate variables along migration routes and locally at bird observatories (Ahola, 2004; Jonzén et al., 2007; Miles et al., 2017; Lehikoinen et al., 2019). We suggest a more complex explanation for these temporal shifts of spring migration timing as a combined effect of two phenomena: 1 ) changes in climate factors, some with multiyear trends and others without, which have different effects on different cohorts of migrating Willow Warblers; 2) different selection pressures on early- and late-arriving male and female Willow Warblers.

Firstly, we suggest that the varied advance of the Willow Warbler passage at Bukowo in three main periods of spring was caused by the sequential passage of different migratory populations, which arrive from different parts of the wintering range where they had been affected by different climatic conditions. These populations then mix at the site in proportions that vary over the season. Of the nine climate variables that were related to the timing of the 
491 Willow Warblers' passage through Bukowo (Table 3), the values of PSAH and TSAH (Aug-

492 Oct_1y) and temperatures in Łeba (Apr-May) increased significantly over the 36 years of study

493 (Table S6). PSAH and TSAH (Aug-Oct_1y) were related with the timing of migration in the

494 first two main periods of spring (Table 3); these climate factors might therefore help explain the

495 long-term trend towards an earlier passage in spring (Fig. 3A-B). Analogously, long-term

496 increases in TLEB (Apr-May) likely contributed to the advance in the middle period of spring,

497 along with PSAH (Fig. 3B). TLEB (Apr-May) was the only climate variable with a long-term

498 increase that influenced the timing of the species' passage in the last period of spring (Table 3),

499 which by acting alone explained the smaller advance than in the other periods (Fig. 3C). Year as

500 the only explanatory variable was significantly related to anomalies in the first and second main

501 periods of spring (Fig. 3, Table S7). However when used in conjunction with the other climate

502 variables, year was not selected in any of the best models (Table 3). This indicated that the effect

503 of the year was absorbed by the climate variables that accounted for the long-term trends in the

504 timing of migration. Other climate indices showed no clear trend, but their year-to-year changes

505 contributed to the interannual variability in Willow Warblers' spring migration timing, as in

506 other migrants (e.g. Tomotani et al. 2021).

507 Secondly, selection pressures might act differently on the sexes, especially in protandrous

508 species in which males arrive at the breeding grounds ahead of the females. The selection

509 pressures for early arrival vary between males and females (Kokko, 1999; Morbey \& Yndenberg,

510 2001; Kokko et al., 2006; Spottiswoode, Tøttrup \& Coppack, 2006; Lerche Jørgensen et al.,

511 2018). Protandry in Willow Warblers has increased in the Baltic region over 1990-2012

512 (Hedlund et al., 2015). The prevalence of males, pressed for early arrival, among the first spring

513 migrants at Bukowo (Šoštarić, 2016) likely contributed to the shift towards an earlier passage in

514 the first and the middle of the three main periods of spring that we found over 1982-2017.

515 The explanation for larger long-term shifts to an earlier passage in the first two periods of

516 spring rather than in the third period likely lies within the combined influences of long-term

517 increases in climate indices that reflect wetter or warmer winters and springs, which favour

518 migrants' survival and the selection pressure for early arrival, the evolutionary mechanism that

519 drives the migrants' adjustment to these changes (Kokko, 1999; Kokko et al., 2006). 
521 Temporal variation in the effects of climate indices on the timing of spring passage at

\section{Bukowo}

523 Ph. t. acredula winters mainly in eastern Africa (Zhao et al., 2020), where IOD reflects rainfall 524 and temperatures (Marchant et al., 2006), and in southern Africa (Herremans, 1999; Zhao et al., 525 2020), where SOI reflects these climate features (McPhaden, Santoso \& Cai, 2020). But Ph.t.

526 trochilus winters mainly in western Africa (Bensch et al. 2009; Zhao et al., 2020), where TSAH, 527 PSAH and winter NAO reflect climatic conditions (Hurrell, 1995; Munemoto \& Tachibana, 528 2012). Indices of climate in southern and eastern Africa dominated the results of our analysis of 529 the early part of spring; those related to climate in western Africa had a weaker effect on the 530 early passage, but peaked in middle and late spring (Table 3, Fig. 4, Table S14). One possible 531 explanation would be that populations from southern and eastern Africa, probably of $P h$. $t$. 532 acredula, begin arriving at Bukowo early in the migration period, and that populations from 533 western Africa, likely of Ph. t. trochilus, arrive throughout the migration period, but peak in the 534 middle and last part. This would be a different sequence to that in which they arrive in central 535 Sweden, where Ph. t. acredula occur about two weeks later than Ph. t. trochilus (Hedenström \& 536 Pettersson, 1984; Bensch, Andersson \& Akesson, 1999). Another explanation might be that some 537 Ph. t. trochilus during wintering or stopovers visit areas under climatic influence of IOD and 538 SOI, and some Ph. t. acredula visit areas influenced by TSAH, PSAH and NAO, for the exact 539 contact zone between the subspecies in Africa remains unknown (Urban, Fry \& Keith, 1997; 540 Zhao et al., 2020).

$541 \quad$ Under the first scenario, Ph. t. acredula would arrive early at Bukowo probably because 542 they are heading to their breeding grounds farther north than Ph. t. trochilus. Bukowo lies within 543 the southern part of the breeding range of the trochilus subspecies, whose northern limits cross 544 central Sweden ca 600-950 km further north (Fig. 1). Ph. t. acredula still have to fly another 545 600-3000 km from Bukowo to reach their more northerly breeding grounds (Fig. 1). Assuming 546 Willow Warblers' migrate at $66 \mathrm{~km}$ /day in spring, based on ringing recoveries within the Baltic 547 region (Supplement 3), the birds would take about nine days to cover the $600 \mathrm{~km}$ from Bukowo 548 to central Sweden across the Baltic Sea, but several days more to reach northern Sweden, and 549 about a month to reach the northeastern part of their breeding range, where Ph. t. acredula 550 predominate (Fig. 1). Under the second scenario, the early cohorts of migrants would mainly 551 consist of populations arriving from the eastern and southeastern part of the species' wintering 
552 range, influenced by the IOD and SOI, but no apparent sequence of subspecies' arrivals should

553 occur at Bukowo. The sequence of the subspecies' passage should be verified in future by 554 genotyping (Zhao et al., 2020) and through tracking Willow Warblers by geolocators or other 555 devices (Lerche-Jørgensen et al., 2017; Sokolovskis et al., 2018).

556 Interannual variations in sex ratios would likely contribute to the effects of climate 557 variables on spring phenology, given Willow Warblers' protandry (Hedlund et al., 2015) and the 558 likely stronger response of the males to temperatures at the wintering grounds, as in other 559 passerines (Redlisiak \& Remisiewicz, 2021). Arrivals in spring would therefore be late on 560 average in years with a low proportion of males in the migratory population, despite favourable 561 conditions, and vice versa. This could be tested by studies involving DNA sexing (Šoštarić 562 2016). Analogously, the year-to-year changes in the proportion of age groups among migrating 563 Willow Warblers' might also contribute to the effects of climate variables on arrivals at Bukowo. 564 If adults migrate earlier than immatures, as in other passerines (Newton, 2011), then in years 565 with a low proportion of adults in the migratory population of Willow Warblers would arrive 566 later on average in spring than in years with a high proportion of adults. We discuss this possible influence of age ratios in more detail for the SCAND index, but this factor would likely affect all

568 the climate indices.

569

570

Effects of IOD and SOI

571 The timing of Willow Warblers' passage through Bukowo in the first main period of spring (157226 April) was more strongly related to IOD and SOI in Aug-Oct of the previous year than to any 573 other climate index (Table 3, Fig. 4A-B, Table S14). The possible explanation might be that the 574 populations visiting eastern and southern parts of the species' non-breeding range and influenced 575 by these climate indices predominated the passage throughout April, but in May their proportion 576 decreased. The dates when the first 5\% of Willow Warblers arrive at the Hanko Bird

577 Observatory in Finland are correlated with April temperatures in the Balkans, southeast of both 578 Hanko and Bukowo (Halkka, Lehikoinen \& Velmala, 2011); which is in line with our results. 579 Conditions at eastern African stopover sites, where IOD operates (Fig. 1), influence the birds' 580 speed at subsequent stages of migration and thus the timing of their arrival in northern Europe, as 581 with Nightingales Luscinia megarhynchos and Redstarts Phoenicurus phoenicurus (Tøttrup et 582 al., 2012). Willow Warblers on passage to and from southern Africa likely use stopovers in 
583 eastern Africa (Fig. 1), which might contribute to the effect IOD shows on the passage at

584 Bukowo. The timing of Willow Warblers' spring passage was related to IOD and PSAH, as for

585 White Storks Ciconia ciconia arriving in Poland from wintering grounds in southeastern and

586 western Africa (Tobolka et al., 2018).

587

588 Effects of precipitation and temperature in the Sahel

589 The influence of rainfall and temperatures in the Sahel on Willow Warblers' spring arrivals at

590 Bukowo (Table 3, Fig. 1C-E) that we found was in line with the influence of these climate

591 features in western Africa on the species' spring phenology at Helgoland, Germany (Haest,

592 Hüppop \& Bairlein, 2020). Those authors interpret this phenomenon as the influence of

593 conditions at wintering or stopover sites in western Africa on populations arriving at Helgoland;

594 we suggest an analogous explanation for Bukowo. Our results, which suggest that Willow

595 Warblers arrive at Bukowo early after a wet and warm August-October of the previous year and

596 after a wet November-December in the Sahel, correspond with the earlier arrival of the species

597 at Helgoland after wet winters in that region of Africa (Haest, Hüppop \& Bairlein, 2020). Our

598 results also correspond with the higher survival of Sahara crossings by Willow Warblers after

599 winters with a high Sahel Precipitation Index (Zwarts et al., 2009). The early arrival of spring

600 migrants in Capri, Italy, (Saino et al., 2007) and the Iberian Penninsula (Gordo \& Sanz, 2008)

601 was related to wet winters in the Sahel, as in our study. The effect of temperatures in the Sahel

602 that we found correspond with the early arrival of long-distance migrants, including our study

603 species, in the UK, over 1966-2011 in years with high temperatures in sub-Saharan western and

604 eastern Africa (Cotton, 2003).

605

606 Effects of winter NAO

607 Many passerines, including Willow Warblers, arrive in Europe early after a positive winter NAO

608 (Dec-March), which is related to an early and warm spring in Europe (e.g. Forchhammer, Post \& 609 Stenseth, 2002; Hüppop \& Hüppop, 2003; Ahola, 2004; Vähätalo et al., 2004; Rainio et al., 610 2006; Gordo, 2007; Jonzén et al., 2007; Saino \& Ambrosini, 2008). The relationship of Willow

611 Warblers' passage throughout spring at Bukowo to NAO in Nov-March (Table 3, Fig. 1F)

612 corresponds with the relationship between NAO (Dec-March) and all phases of Willow Warbler 613 spring migration through Hanko and Jurmo, Finland, and Helgoland, Germany (Vähätalo et al., 
614 2004; Sparks et al., 2005). NAO (Nov-March) influences the conditions that Willow Warblers 615 experience on spring stopovers in western Africa and in southwestern Europe (Fig. 1). This 616 climate index influenced the species' timing in all nine sub-periods of spring (Fig. 4F), 617 suggesting that Willow Warblers from these areas migrate through Bukowo throughout the 618 season. The weaker relationship of spring migration timing at Bukowo with NAO (Nov-March) 619 than with other climate indices (Table 3, Fig. 1F) corresponds with winter NAO explaining a 620 small part of the variation in this species' spring phenology at Helgoland (Haest, Hüppop \& 621 Bairlein, 2018). Those results and our study show that other climate indices likely have a greater 622 influence on the spring phenology of this species in Europe than winter NAO.

623

624 Effect of spring NAO

625 The relationship between Willow Warblers' migration timing and NAO (Apr-May) that we 626 found (Table 3, Fig. 4G) corresponds with the influence of winds and temperatures in these 627 months at stopovers in southwestern and western Europe has on this species' spring migration at 628 Helgoland (Haest, Hüppop \& Bairlein, 2020). NAO of Apr-May was not related to local 629 temperatures in Łeba in Apr-May (Table S5). Thus the relation of NAO (Apr-May) to Willow 630 Warblers' passage probably reflected conditions that influnce these birds passage at more distant 631 stopovers than the Polish coast.

632

\section{Effects of local temperatures in April-May}

634 We found that local temperatures had no significant effect on the timing of Willow Warblers' 635 arrivals at Bukowo in the first main period of spring (Table 3, Fig. 4H). This is contrary to 636 correlations found between First Arrival Dates (FADs) of Willow Warblers and other passerines 637 and local spring temperatures at observatories in Helgoland in Germany, Jurmo in Finland, and 638 Rybachy and Ladoga in Russia (Sparks et al., 2005), as well as the relationships between local 639 temperatures and the timing of the first $5 \%$ of spring passage at Helgoland, Christiansø in 640 Denmark, and Jurmo (Tøttrup et al., 2010). One reason for these differences might be that FADs 641 are influenced by population numbers, the detectability of the species and observation effort 642 (Tryjanowski \& Sparks 2001, Lindén 2011). Annual Anomalies we used are based on a daily 643 percentage of the total catch in a season, and thus are less sensitive to the occurrence of the first 644 birds in an area than studies based on FADs. Another reason would be that we analysed the 
645 effect of local temperatures in the context of a far wider range of climate variables, such as SOI 646 and IOD, which seemingly better explained variations in the timing of our study species' arrivals 647 in early spring. Spring conditions at the Baltic coast, even the most favourable, would not have 648 attracted the migrants any earlier had they not departed early from their wintering grounds 649 several weeks before arrival.

650 Local temperatures had the greatest effect on Willow Warblers at Bukowo in the middle 651 of spring (Table 3, Fig. 4H), the period where the mean and median dates of the migration 652 passage occur (Remisiewicz \& Underhill, 2020). This finding corresponds with correlations of 653 mean or middle dates of this species' passage with local spring temperatures at other locations in 654 Europe (Sokolov et al., 1998; Hüppop \& Hüppop, 2003; Sparks et al., 2005; Lehikoinen et al., 655 2019). The moderate influence of local temperatures on migration in late spring at Bukowo was 656 analogous to the weak relationships of the $95 \%$ of passage in this and other passerines to 657 temperatures at many sites in the northern hemisphere (Lehikoinen et al., 2019).

The pattern of relationships between local temperatures and Willow Warblers' spring migration timing at Bukowo is likely a combination of several effects. Firstly, birds using a stopover location, such as Bukowo or other bird observatories, do not experience the temperature at that site during the earlier stages of their migration. Any link between their passage and local temperatures is not a cause-and-effect relationship, but the effect of temperatures being correlated over wide areas (Koenig, 1999). The correlation of temperatures in northern Europe with those at previous stopovers in southern Europe and northern Africa might cue long-distance migrants to adjust their arrivals to conditions near and at the breeding grounds (Saino \& Ambrosini, 2008; Tøttrup et al., 2008; Tøttrup et al., 2010; Haest, Hüppop \& Bairlein, 2020; Brown et al., 2021). Temperatures in southern Europe during stopovers influence the timing of migrants' arrivals at more northern sites (Gordo, 2007; Halkka, Lehikoinen \& Velmala, 2011; Briedis, Hahn \& Adamík, 2017).

The second and more direct way that local temperatures influence migration dynamics might be their effect on the availability of insects at stopovers, including those near bird observatories. An abundance of insects depends on weather, which shapes the activity of

673 insectivorous migrants that forage more intensively on warm days than on cold days (Stokke et 674 al., 2005). Intensive foraging by birds ensures good catches in mist nets. The calls of active birds 675 also attract more passing migrants to land at a good stopover site (Chernetsov, 2012). Large 
676 catches on days with favourable conditions influence the measures of migration at a site

677 (Knudsen et al., 2007), such as the mean migration dates, dates of percentiles and our Annual

678 Anomaly (Sokolov et al., 1998; Hüppop \& Hüppop, 2003; Sparks et al., 2005; Lehikoinen et al.,

679 2019; Remisiewicz \& Underhill, 2020). Warm days occur less frequently at Bukowo in the first

680 half of April than later in the season (Šoštarić, 2016), thus the effect of local conditions is likely

681 to be pronounced later in spring, concurring with our results.

682

683

684

\section{Effects of Scandinavian conditions in summer and the number of juveniles in autumn on} the timing of migration in the next spring

685

The relationship between Willow Warblers' spring passage through Bukowo and the count of

686 migrating immatures caught the previous August-October and the SCAND index in June-July of

687 the previous year probably reflects conditions in the breeding season preceding spring passage.

688 Spring migration at Bukowo shifted later when SCAND (Jun-July_1y) was low and the count of juveniles in the previous autumn was large (Njuv_1y), and vice versa (Table 3, Fig. 5). The effect of SCAND (Jun-July_1y) on the mid- and last three main periods of spring passage (Table 3, Fig. 4I) was the strongest shown by all the climate variables, in line with the conclusion of Ockendon et al. (2013) that conditions on the breeding grounds are the main drivers of changes in the breeding phenology and nesting success for long-distance migrants, including Willow Warblers. The partial AAs reflect the timing and the numbers of the migration passage through Bukowo in each period of spring in relation to a multiyear baseline (Remisiewicz \& Underhill, 2020). Thus AA might relate not only to climatic variation that influences the timing of arrivals but also to the demography of the spring passage (Gordo, 2007). survival of insectivores and their nestlings, and so the demography of a population (Stokke et al., 2005). In summer, the positive phase of SCAND is related to high temperatures and low precipitation in Scandinavia (Bueh \& Nakamura, 2007), which should provide good feeding conditions for the insectivorous Willow Warblers in the breeding season (Fig. 1). Occurrences of Willow Warblers in greater numbers at Bukowo in springs after summers with a high SCAND, and thus likely a more successful previous breeding season in Scandinavia, would shift the bulk of the species' passage to later dates, as the cohorts that responded to SCAND occurred at 
706 Bukowo in middle and late periods of spring. This would cause negative values of the AA index

707 for late passage (Remisiewicz \& Underhill, 2020).

708 Nevertheless, the lack of a correlation between the count of juvenile Willow Warblers in

709 autumn at Bukowo and SCAND in June-July the previous year suggested that summer

710 conditions in Scandinavia were not the main underlying reason for the relationship between

711 Njuv_ly in autumn the previous year and the timing of migration in spring. The lack of a

712 relationship might be an effect of the sequential passage of different migratory populations in

713 autumn and in spring, including Ph. t. acredula from breeding grounds east of the influence of

714 SCAND (Fig. 1). Based on ringing recoveries from Willow Warblers' breeding grounds north of

715 Bukowo (Fransson \& Hall-Karlsson, 2008; Valkama et al., 2014; Maciąg et al., 2017), we had

716 assumed that the same breeding populations migrate through the site in spring and autumn, but

717 likely in different proportions over the seasons and the years, depending on local weather.

718 Juveniles constituted $76 \%-100 \%$ of all Willow Warblers caught in autumn (Table S2), probably

719 because of the "coastal effect", whereby young birds use stopovers on the coastline more often

720 than the more experienced adults (Payevsky, 1998). Thus we did not use the proportion of

721 juveniles to adults as a measure of the species' breeding success, as in other studies (e.g. Barshep

722 et al., 2011; Newton \& Dawson, 2011).

723 Young Willow Warblers at the end of their first year of life are indistinguishable from

724 adults (Svensson, 1992; Demongin, 2016) after a complete moult at the wintering grounds

725 (Underhill et al., 1992), so we could not age the birds we caught in spring at Bukowo. But if

726 adults arrive at the breeding grounds ahead of young birds, as in other passerines (Newton,

727 2011), then adults likely dominated the cohort of early migrants of this species and the young

728 birds arrived later at Bukowo on average. Young birds would be better represented after a

729 summer with high breeding success more than after a poor breeding season. Young birds arriving

730 in spring later than adults, and in large numbers after summers with good breeding success,

731 would shift the peak of passage later, reflected by lower AA values in mid-spring, than after

732 summers with low breeding success. Thus we suggest that the later spring migration at Bukowo

733 after a higher count of Njuv in autumn probably reflected the demography of migrating cohorts

734 of Willow Warblers.

735

736

CONCLUSIONS 
737 We showed that the pattern of Willow Warbler arrivals in spring at the southern coast of the

738 Baltic was sequentially influenced by indices of climate in different parts of the species' winter 739 range. The climatic variability that some populations experienced on their wintering grounds in 740 southern and eastern Africa had carryover effects on the timing of the species' arrivals in 741 northern Europe in early spring; the indices of climate in western Africa strongly affected the 742 populations arriving in the middle and the end of spring. Climate change and year-to-year

743 variation of weather at the wintering grounds enable long-distance migrants to depart earlier after 744 favourable conditions (e.g. Katti \& Price, 1999; González, Bayly \& Hobson, 2021; Tomotani et 745 al., 2021). Conditions at stopover sites influence the rate of spring migration (e.g. Tøttrup et al., 746 2012; Aloni, Markman \& Ziv, 2019). The gradually warmer spring season in the northern 747 hemisphere favours the early breeding of migrants (Ouwehand \& Both, 2017; Hoover \& 748 Schelsky, 2020). Our results showed that climate changes at remote wintering grounds and at 749 stopover sites are important drivers of changes in the arrival timing of migrants in Europe. These

750 factors operate in combination with climate change in the northern hemisphere. The overall

751 effect is a shift to earlier spring arrivals in the north that enables earlier breeding, which has been 752 shown to contribute to phenological shifts in the life stages of long-distance migrants such as 753 Barn Swallow (Burman, 2016), Pied Flycatcher (Ouwehand \& Both, 2017; Tomotani et al., 754 2018) and Willow Warbler (Hedlund et al., 2015; Remisiewicz \& Underhill, 2020; this study).

755 We propose that the analysis of temporal changes in the relationships between migration 756 parameters and climate indices at different winter quarters and at stopovers is a useful tool to 757 unravel the arrival patterns in species that use widespread wintering grounds, such as many 758 Euro-African migrant birds.

759

760 ACKNOWLEDGEMENTS

761 The data at Operation Baltic's Bukowo ringing station have been collected over the years by 762 hundreds of citizen scientists who have made a decisive contribution to this paper. The staff of 763 the Bird Migration Research Station, especially Krzysztof Stępniewski and Agata Pinszke, 764 compiled the databases on ringed Willow Warblers. Eva Poślińska, Michał Redlisiak and Joanna 765 Gruchocka compiled climate databases. We downloaded monthly values for most climate indices 766 from the US National Oceanic and Atmospheric Administration, National Weather Service, 767 Climate Prediction Center (http://www.cpc.ncep.noaa.gov/). We used the monthly Sahel 
768 Precipitation Index (SAH) provided by the Joint Institute for the Study of the Atmosphere and 769 Ocean, College of the Environment, University of Washington, US

770 (http://research.jisao.washington.edu/data/sahel/sahelprecip19012017), and the monthly Sahel

771 Temperature Anomaly provided by KNMI Climate Explorer and the European Centre for

772 Medium-Range Weather Forecasts (http://climexp.knmi.nl). We downloaded the mean daily

773 temperatures of the Leba weather station from the European Climate Assessment and Dataset

774 (

775 The comments from three anonymous reviewers, Leslie Ries and Simon Griffith improved the 776 manuscript. Joel Avni commented on and edited earlier drafts.

777

778 Supplemental Information

779 Supplemental information for this article can be found online at XXX.

780

781 REFERENCES

782 Ahola M, Laaksonen T, Sippola K, Eeva T, Rainio K, Lehikoinen E. 2004. Variation in climate 783 warming along the migration route uncouples arrival and breeding dates. Global Change Biology 784 10:1610-1617. DOI: 10.1111/j.1365-2486.2004.00823.x.

785 Aloni I, Markman S, Ziv Y. 2019. Autumn temperatures at African wintering grounds affect 786 body condition of two passerine species during spring migration. Plos One 14:e0217619. DOI: 787 10.1371/journal.pone.0217619.

788 Altwegg R, Broms K, Erni B, Barnard P, Midgley GF, Underhill LG. 2012. Novel methods 789 reveal shifts in migration phenology of barn swallows in South Africa. Proceedings of the Royal 790 Society B: Biological Sciences 279:1485-1490. DOI: 10.1098/rspb.2011.1897.

791 Bairlein F, Dierschke J, Dierschke V, Salewski V, Geiter O, Hüppop K, Köppen U, Fiedler W. 792 2014. Atlas des Vogelzugs: Ringfunde Deutscher Brut- und Gastvögel. Wiebelsheim: AULA793 Verlag.

794 Balbontín J, Møller AP, Hermosell IG, Marzal A, Reviriego M, de Lope F. 2009. Individual 795 responses in spring arrival date to ecological conditions during winter and migration in a 796 migratory bird. Journal of Animal Ecology 78:981-989. DOI: 10.1111/j.1365797 2656.2009.01573.x.

798 Barshep Y, Minton C, Underhill LG, Remisiewicz M. 2011. The primary moult of curlew 
799 sandpipers Calidris ferruginea in north-western Australia shifts according to breeding success. 800 Ardea 99:43-51. DOI: 10.5253/078.099.0106.

801 Bartoń K. 2019.Package 'MuMIn'. Multi-Model Inference. Available at https://cran.r802 project.org/web/packages/MuMIn/MuMIn.pdf. (accessed November 20, 2019).

803 Benjamini Y., Hochberg Y. 1995. Controlling the false discovery rate: a practical and powerful 804 approach to multiple testing. Journal of the Royal Statistical Society, Series B 57 (1): 289-300.

805 Bensch S, Andersson T, Åkesson S. 1999. Morphological and molecular variation across a 806 migratory divide in willow warblers, Phylloscopus trochilus. Evolution 53 (6):1925-1935.

807 Bensch S, Bengtsson G, Åkesson S. 2006. Patterns of stable isotope signatures in Willow 808 Warbler Phylloscopus trochilus feathers collected in Africa. Journal of Animal Ecology 37:323809330.

810 Bensch S, Grahn M, Müller N, Gay L, Åkesson S. 2009. Genetic, morphological, and feather 811 isotope variation of migratory willow warblers show gradual divergence in a ring. Molecular 812 Ecology 18:3087-3096. DOI: 10.1111/j.1365-294X.2009.04210.x.

813 Briedis M, Hahn S, Adamík P. 2017. Cold spell en route delays spring arrival and decreases 814 apparent survival in a long-distance migratory songbird. BMC Ecology:1-8. DOI: 815 10.1186/s12898-017-0121-4.

816 Brown JN, van Loon EE, Bouten W, Camphuysen KC, Lens L, Müller W, Thaxter CB, 817 Shamoun-Baranes J. 2021. Long-distance migrants vary migratory behaviour as much as 818 short-distance migrants: an individual-level comparison from a seabird species with diverse 819 migration strategies. Journal of Animal Ecology. DOI: 10.1111/1365-2656.13431.

820 Bueh C, Nakamura H. 2007. Scandinavian pattern and its climatic impact. Quarterly Journal of 821 the Royal Meteorological Society 133:2117-2131. DOI: 10.1002/qj.

822 Burman MS. 2016. Citizen science reveals complex changes in barn swallow phenology in South 823 Africa over three decades. PhD thesis, University of Cape Town. Available at:

824 https://open.uct.ac.za/handle/11427/22801

825 Busse P, Meissner W. 2015. Bird Ringing Station Manual. Warsaw/Berlin: De Gruyter Open 826 Ltd.

827 Bussière EMS, Underhill LG, Altwegg R. 2015. Patterns of bird migration phenology in South 828 Africa suggest northern hemisphere climate as the most consistent driver of change. Global 829 Change Biology 21:2179-2190. DOI: 10.1111/gcb.12857. 
830 Cepák J, Klwaňa P, Škopek J, Schröpfer L, Jelínek M, Hořák D, Formánek J, Zárybnický J.

831 2008. Atlas migrace ptákû České republiky a Slovenska. Prague: Aventinum.

832 Chambers LE, Barnard P, Poloczanska ES, Hobday AJ, Keatley MR, Allsopp N, Underhill LG.

833 2017. Southern Hemisphere biodiversity and global change: Data gaps and strategies. Austral

834 Ecology 42:20-30. DOI: 10.1111/aec.12391.

835 Chernetsov N. 2012. Passerine Migration. Stopovers and Flight. Berlin Heidelberg: Springer-

836 Verlag Berlin Heidelberg 2012.

837 Cotton PA. 2003. Avian migration phenology and global climate change. Proceedings of the

838 National Academy of Sciences 100:12219-12222.

839 Cramp S, Brooks DJ. 1992. The Birds of the Western Palearctic. Handbook of the Birds of

840 Europe, the Middle East and North Africa. Vol. VI: Warblers. Oxford: Oxford University Press.

841 Crawley MJ. 2013. The R Book. Chichester, England: John Wiley \& Sons.

842 Dean WRJ. 2005. Willow Warbler Phylloscopus trochilus. In: Hockey PAR. Dean WRJ, Ryan

843 PG eds Roberts'Birds of Southern Africa, VIIth ed. Cape Town: Trustees of the John Voelcker

844 Bird Book Fund, 807-808.

845 Demongin L. 2016. Identification guide to Birds in the Hand. Beauregard-Vendon: Laurent

846 Demongin.

847 Dormann CF, Elith J, Bacher S, Buchmann C, Carl G, Carr G, Garc JR, Gruber B, Lafourcade B, 848 Leit PJ, Tamara M, Mcclean C, Osborne PE, Der BS, Skidmore AK, Zurell D, Lautenbach S.

849 2013. Collinearity: a review of methods to deal with it and a simulation study evaluating their

850 performance. Ecography 36:27-46. DOI: 10.1111/j.1600-0587.2012.07348.x.

851 Finnish Museum of Natural History. 2017. Population indices of breeding in Finland. Dataset

852 provided by Valkama JP, Lehikoinen SA, Sirkiä PM (accessed June 06, 2017).

853 Forchhammer MC, Post E, Stenseth NCHR. 2002. North Atlantic Oscillation timing of long- and

854 short-distance migration. Journal of Animal Ecology 71:1002-1014.

855 Fransson T, Hall-Karlsson S. 2008. Svensk Ringmärkningsatlas. Vol. 3. Stockholm:

856 Naturhistoriska riksmuseet \& Sveriges Ornitologiska Forening.

857 Frost J. 2019. Regression analysis. An intuitive guide for using and interpreting linear models.

858 First Edition. Jim Frost. Available at: statisticsbyjim.com.

859 González-Prieto AM, Hobson KA. 2013. Environmental conditions on wintering grounds and

860 during migration influence spring nutritional condition and arrival phenology of Neotropical

Peer] reviewing PDF | (2020:12:56300:3:1:NEW 24 Jan 2022) 
861 migrants at a northern stopover site. Journal of Ornithology 154:1067-1078. DOI:

862 10.1007/s10336-013-0975-y.

863 González AM, Bayly NJ, Hobson KA. 2021. Earlier and slower or later and faster: Spring

864 migration pace linked to departure time in a Neotropical migrant songbird. Journal of Animal

865 Ecology. DOI: 10.1111/1365-2656.13359.

866 Gordo O. 2007. Why are bird migration dates shifting? A review of weather and climate effects

867 on avian migratory phenology. Climate Research 35:37-58. DOI: 10.3354/cr00713.

868 Gordo O, Barriocanal C, Robson D. 2011. Ecological impacts of the North Atlantic Oscillation

869 (NAO) in Mediterranean ecosystems. In: Vicente-Serrano SM, Trigo RM eds. Hydrological,

870 Socioeconomic and Ecological Impacts of the North Atlantic Oscillation in the Mediterranean

871 Region. Springer Science+Business Media B.V., 153-170.

872 Gordo O, Sanz JJ. 2008. The relative importance of conditions in wintering and passage areas on

873 spring arrival dates : the case of long-distance Iberian migrants. Journal of Ornithology 149:199-

874 210. DOI: 10.1007/s10336-007-0260-z.

875 Green M, Haas F, Lindström Å. 2017. Monitoring population changes of birds in Sweden.

876 Annual report for 2016. Department of Biology, Lund University. 84 pp.

877 Haest B, Hüppop O, Bairlein F. 2018. Challenging a 15-year-old claim: The North Atlantic

878 Oscillation index as a predictor of spring migration phenology of birds. Global Change Biology

$87924: 1523-1537$.

880 Haest B, Hüppop O, Bairlein F. 2020. Weather at the winter and stopover areas determines

881 spring migration onset, progress, and advancements in Afro-Palearctic migrant birds.

882 Proceedings of the National Academy of Sciences:1-7. DOI: 10.1073/pnas.1920448117.

883 Halkka A, Lehikoinen A, Velmala W. 2011. Do long-distance migrants use temperature

884 variations along the migration route in Europe to adjust the timing of their spring arrival? Boreal

885 Environment Research16 (Suppl. B):35-48.

886 Halupka L, Wierucka K, Sztwiertnia H, Klimczuk E. 2017. Conditions at autumn stopover sites

887 affect survival of a migratory passerine. Journal of Ornithology 158:979-988. DOI:

888 10.1007/s10336-017-1472-5.

889 Hedenström A, Pettersson J. 1984. Lövsångarens Phylloscopus trochilus flyttning vid Ottenby.

890 Vår Fågelvärld 43:217-228. 
891 Hedenström A, Pettersson J. 1987. Migration routes and wintering areas of Willow Warblers

892 Phylloscopus trochilus (L.) ringed in Fennoscandia. Ornis Fennica 64(4): 137-143.

893 Hedlund JSU, Jakobsson S, Kullberg C, Fransson T. 2015. Long-term phenological shifts and

894 intra-specifi c differences in migratory change in the willow warbler Phylloscopus trochilus.

895 Journal of Avian Biology 46:97-106. DOI: 10.1111/jav.00484.

896 Herremans M. 1999. Willow Warbler Phylloscopus trochilus. In: Harrison JA, Allan DG,

897 Underhill LG, Herremans M, Tree AJ, Parker V, Brown CJ eds. The Atlas of Southern African

898 Birds. Vol. 2: Passerines. Johannesburg: BirdLife South Africa, 254-255.

899 Hoover JP, Schelsky WM. 2020. Warmer April temperatures on breeding grounds promote

900 earlier nesting in a long-distance migratory bird, the prothonotary warbler. Frontiers in Ecology

901 and Evolution 8: 427. DOI: 10.3389/fevo.2020.580725.

902 Hurrell JW. 1995. Decadal trends in the North Atlantic Oscillation: Regional temperatures and

903 precipitation. Science 269:676-679. DOI: 10.1126/science.269.5224.676.

904 Hüppop O, Hüppop K. 2003. North Atlantic Oscillation and timing of spring migration in birds.

905 Proceedings of the Royal Society B: Biological Sciences 270:233-240. DOI:

906 10.1098/rspb.2002.2236.

907 Hušek J, Adamík P, Cepák J, Tryjanowski P. 2008. The influence of climate and population size

908 on the distribution of breeding dates in the Red-backed Shrike (Lanius collurio). Annales

909 Zoologici Fennici 46:439-450.

910 Jonzén N, Ergon T, Lindén A, Stenseth NC. 2007. Bird migration and climate: The general

911 picture and beyond. Climate Research 35:177-180. DOI: 10.3354/cr00724.

912 Jørgensen PS, Böhning-Gaese K, Thorup K, Tøttrup AP, Chylarecki P, Jiguet F, Lehikoinen A,

913 Noble DG, Reif J, Schmid H, van Turnhout C, Burfield IJ, Foppen R, Voříšek P, van Strien A,

914 Gregory RD, Rahbek C. 2016. Continent-scale global change attribution in European birds -

915 combining annual and decadal time scales. Global Change Biology 22:530-543. DOI:

$91610.1111 / \mathrm{gcb} .13097$.

917 Katti M, Price T. 1999. Annual variation in fat storage by a migrant warbler overwintering in the

918 Indian tropics. Journal of Animal Ecology 68:815-823. DOI: 10.1046/j.1365-

919 2656.1999.00331.x.

920 Kim S. 2015. ppcor: An R package for a fast calculation to semi-partial correlation coefficients.

921 Communications for Statistical Applications and Methods 22(6): 665-674.

Peer] reviewing PDF | (2020:12:56300:3:1:NEW 24 Jan 2022) 
922 Kluen E, Nousiainen R, Lehikoinen A. 2017. Breeding phenological response to spring weather

923 conditions in common Finnish birds: resident species respond stronger than migratory species.

924 Journal of Avian Biology 48:611-619. DOI: 10.1111/jav.01110.

925 Knudsen E, Lindén A, Ergon T, Jonzén N, Vik JO, Knape J, Røer JE, Stenseth NC. 2007.

926 Characterizing bird migration phenology using data from standardized monitoring at bird 927 observatories. Climate Research 35:59-77. DOI: 10.3354/cr00714.

928 Koenig WD. 1999. Spatial autocorrelation of ecological phenomena. Trends in Ecology \& 929 Evolution 14(1): 22-26.

930 Kokko H. 1999. Competition for early arrival in migratory birds. Journal of Animal Ecology $93168: 940-950$.

932 Kokko H, Gunnarson T, Morrel LJ, Gill JA. 2006. Why do female migratory birds arrive later 933 than males? Journal of Animal Ecology 75:1293-1303.

934 Lehikoinen A, Lindén A, Karlsson M, Andersson A, Crewe TL, Dunn EH, Gregory G, Karlsson

935 L, Kristiansen V, Mackenzie S, Newman S, Erik J, Sharpe C, Sokolov LV., Steinholtz Å, 936 Stervander M, Tirri I-S, Tjørnløv RS. 2019. Phenology of the avian spring migratory passage in 937 Europe and North America : Asymmetric advancement in time and increase in duration.

938 Ecological Indicators 101:985-991. DOI: 10.1016/j.ecolind.2019.01.083.

939 Lerche-Jørgensen M., Korner-Nievergelt F., Tøttrup AP, Willemoes M, Thorup K. 2018. Early

940 returning long-distance migrant males do pay a survival cost. Ecology and evolution 8(23):

941 11434-11449. DOI: 10.1002/ece3.4569.

942 Lerche-Jørgensen M, Willemoes M, Tøttrup AP, Snell Scotchburn KR. 2017. No apparent gain

943 from continuing migration for more than 3000 kilometres : willow warblers breeding in Denmark

944 winter across the entire northern Savannah as revealed by geolocators. Movement Ecology 5: 17.

945 DOI: 10.1186/s40462-017-0109-x.

946 Lindén A. 2011. Using first arrival dates to infer bird migration phenology. Boreal Environment

947 Research 16 (suppl. B): 49-60.

948 Maciąg T, Remisiewicz, M. Nowakowski JK, Redlisiak M, Rosińska K, Stępniewski K, 949 Stępniewska K, Szulc J. 2017.Website of the Bird Migration Research Station. Available at 950 http://www.sbwp.ug.edu.pl/badania/monitoringwyniki/ (accessed July 20, 2021).

951 Marchant R, Mumbi C, Behera S, Yamagata T. 2006. The Indian Ocean dipole - the unsung 952 driver of climatic variability in East Africa. African Journal of Ecology 45:4-16. 
953 McPhaden MJ, Santoso A., Cai W. 2020. Introduction to El Niño Southern Oscillation in a

954 Changing Climate. In: McPhaden MJ, Santoso A., Cai W. eds. El Niño Southern Oscillation in a

955 Changing Climate. Geophysical monograph series. Wiley-American Geophysical

956 Union, Hoboken, USA, 1-19. DOI: 10.1002/9781119548164.ch1.

957 Miles WTS, Bolton M, Davis P, Dennis R, Broad R, Robertson I, Riddiford NJ, Harvey PV, 958 Riddington R, Shaw DN, Parnaby D, Reid JM. 2017. Quantifying full phenological event

959 distributions reveals simultaneous advances, temporal stability and delays in spring and autumn

960 migration timing in long-distance migratory birds. Global Change Biology 23:1400-1414. DOI:

$96110.1111 /$ gcb.13486.

962 Miller-Rushing AJ, Lloyd-Evans TL, Primack RB, Satzinger P. 2008. Bird migration times, 963 climate change, and changing population sizes. Global Change Biology 14:1959-1972. DOI:

964 doi:10.1111/j.1365-2486.2008.01619.x.

965 Morbey YE, Yndenberg RC. 2001. Protandrous arrival timing to breeding areas: a review.

966 Ecology Letters 4:663-673.

967 Munemoto M, Tachibana Y. 2012. The recent trend of increasing precipitation in Sahel and the 968 associated inter-hemispheric dipole of global SST. International Journal of Climatology

969 1353:1346-1353. DOI: 10.1002/joc.2356.

970 Newton I, Dawson A. 2011. Seasonal changes in moult, body mass and reproductive condition in 971 siskins Carduelis spinus exposed to daylength regimes simulating different latitudes. Journal of 972 Avian Biology 42:22-28. DOI: 10.1111/j.1600-048X.2010.05249.x.

973 Newton I. 2011. Migration within the annual cycle: species, sex and age differences. Journal of 974 Ornithology 152 (Suppl 1):169-185. DOI: 10.1007/s10336-011-0689-y.

975 Nowakowski JK, Stępniewski K, Stępniewska K. Muś K, Szefler A. 2021. Strona www

976 Programu Badawczego “Akcja Bałtycka”. Uniwersytet Gdański 2012-2012. [Website of the

977 “Operation Baltic” Research Programme]. Available at http://akbalt.ug.edu.pl/ (accessed July 9, 978 2021).

979 Ockendon N, Leech D, Pearce-Higgins JW. 2013. Climatic effects on breeding grounds are more 980 important drivers of breeding phenology in migrant birds than carry-over effects from wintering 981 grounds. Biology Letters 9:20130669. DOI: 10.1098/rsbl.2013.0669. 
982 Ouwehand J, Both C. 2017. African departure rather than migration speed determines variation

983 in spring arrival in Pied Flycatchers. Journal of Animal Ecology 86:88-97. DOI: 10.1111/13659842656.12599.

985 Payevsky VA. 1998. Age structure of passerine migrants at the eastern Baltic coast: the analysis 986 of the "coastal effect." Ornis Svecica 8:171-178.

987 R Core Team. 2020. R: a language and environment for statistical computing. R Foundation for 988 Statistical Computing. Vienna, Austria. Available at https://www.r-project.org (accessed 989 February 5, 2021).

990 Rainio K, Laaksonen T, Ahola M, Vähätalo A V., Lehikoinen E. 2006. Climatic responses in 991 spring migration of boreal and arctic birds in relation to wintering area and taxonomy. Journal of 992 Avian Biology 37:507-515. DOI: 10.1111/j.0908-8857.2006.03740.x.

993 Redlisiak M, Remisiewicz M, Mazur A. 2021. Sex-specific differences in spring migration 994 timing of Song Thrush Turdus philomelos at the Baltic coast in relation to temperatures on the 995 wintering grounds. The European Zoological Journal 88:191-203. DOI:

$99610.1080 / 24750263.2020 .1869842$.

997 Redlisiak M, Remisiewicz M, Nowakowski JK. 2018. Long-term changes in migration timing of 998 Song Thrush Turdus philomelos at the southern Baltic coast in response to temperatures on route 999 and at breeding grounds. International Journal of Biometeorology 62:1595-1605 .DOI:

1000 10.1007/s00484-018-1559-6.

1001 Remisiewicz M, Bernitz Z, Bernitz H, Burman MS, Raijmakers J, Raijmakers J, Underhill LG, 1002 Rostkowska A, Barshep Y, Soloviev SA, Siwek I. 2019. Contrasting strategies for wing-moult 1003 and pre-migratory fuelling in western and eastern populations of Common Whitethroat Sylvia 1004 communis. Ibis.161: 824-838. DOI: 10.1111/ibi.12686.

1005 Remisiewicz M, Underhill LG. 2020. Climatic variation in Africa and Europe has combined 1006 effects on timing of spring migration in a long-distance migrant Willow Warbler Phylloscopus 1007 trochilus. PeerJ 8: e8770. DOI: 10.7717/peerj.8770.

1008 Richard Y, Fauchereau N, Poccard I, Rouault M, Trzaska S. 2001. 20th century droughts in 1009 southern Africa: spatial and temporal variability, teleconnections with oceanic and atmospheric 1010 conditions. International Journal of Climatology: A Journal of the Royal Meteorological Society 1011 21(7): 873-885.

1012 Saino N, Ambrosini R. 2008. Climatic connectivity between Africa and Europe may serve as a 
1013 basis for phenotypic adjustment of migration schedules of trans-Saharan migratory birds. Global 1014 Change Biology 14:250-263. DOI: 10.1111/j.1365-2486.2007.01488.x.

1015 Saino N, Rubolini D, Jonzén N, Ergon T, Montemaggiori A, Stenseth NC, Spina F. 2007.

1016 Temperature and rainfall anomalies in Africa predict timing of spring migration in trans-Saharan 1017 migratory birds. Climate Research 35:123-134. DOI: 10.3354/cr00719.

1018 Salewski V, Altwegg R, Erni B, Falk KH, Bairlein F, Leisler B. 2004. Moult of three Palaearctic 1019 migrants in their West African winter quarters. Journal of Ornithology 145:109-116. DOI: $1020 \quad 10.1007 / \mathrm{s} 10336-004-0020-2$.

1021 Sokolov LV, Markovets MY, Shapoval AP, Morozov YG. 1998. Long-term trends in the timing 1022 of spring migration of passerines on the Courish Spit of the Baltic Sea. Avian Ecology and 1023 Behaviour 1:1-21.

1024 Sokolovskis K, Bianco G, Willemoes M, Solovyeva D, Bensch S, Åkesson S. 2018. Ten grams 1025 and 13,000 km on the wing-route choice in willow warblers Phylloscopus trochilus yakutensis 1026 migrating from Far East Russia to East Africa. Movement ecology, 6: 20. DOI: 10.1186/s404621027 018-0138-0.

1028 Šoštarić I. 2016. Sex differences in morphology and migration timing of Chiffchaff Phylloscopus 1029 collybita and Willow Warbler Phylloscopus trochilus in northern Poland. MSc thesis, Biology 1030 Department, Faculty of Science, University of Zagreb, Croatia. Available at:

1031 http://sbwp.ug.edu.pl/wp-content/uploads/2021/01/sostaric-msc-thesis-cv.pdf(accessed February $10325,2021)$.

1033 Sparks TH, Bairlein F, Bojarinova JG, Hüppop O, Lehikoinen E, Rainio K, Sokolov LV, Walker 1034 D. 2005. Examining the total arrival distribution of migratory birds. Global Change Biology 1035 11:22-30. DOI: 10.1111/j.1365-2486.2004.00887.x.

1036 Spottiswoode CN, Tøttrup AP, Coppack T. 2006. Sexual selection predicts advancement of avian 1037 spring migration in response to climate change. Proceedings of the Royal Society B: Biological 1038 Sciences 273(1605): 3023-3029. DOI: 10.1098/rspb.2006.3688.

1039 Stenseth NC, Ottersen G, Hurrell JW, Mysterud A, Lima M, Chan K, Yoccoz NG, Bjørn A. 1040 2003. Studying climate effects on ecology through the use of climate indices: the North Atlantic 1041 Oscillation, E1 Niño Southern Oscillation and beyond. Proceedings of the Royal Society B:

1042 Biological Sciences 270(1529):2087-2096. DOI: 10.1098/rspb.2003.2415. 
1043 Stokke B, Møller AP, Sæther B-E, Rheinwald G, Gutscher H. 2005. Weather in the breeding 1044 area and during migration affects the demography of a small long-distance passerine migrant. 1045 The Auk 122:637-647.

1046 Svensson L. 1992. Identification Guide to European Passerines. L. Svensson, 216-217. 1047 Thorup K, Araújo MB, Rahbek C, Vega ML, Dasari HP, Willemoes M, Klaassen RHG, 1048 Strandberg R, Tøttrup AP, Wikelski M. 2017. Resource tracking within and across continents in 1049 long-distance bird migrants. Science Advances 3:e1601360. DOI: 10.1126/sciadv.1601360. 1050 Tobolka M, Dylewski L, Wozna JT, Zolnierowicz KM. 2018. How weather conditions in non1051 breeding and breeding grounds affect the phenology and breeding abilities of white storks. 1052 Science of the Total Environment 636:512-518. DOI: 10.1016/j.scitotenv.2018.04.253. 1053 Tomiałojć L, Stawarczyk T. 2003. Awifauna Polski: rozmieszczenie, licAzebność i zmiany. 1054 Wrocław: PTPP "pro Natura."

1055 Tomotani BM., Gienapp P, de la Hera I, Terpstra M, Pulido F, Visser ME. 2021. Integrating 1056 causal and evolutionary analysis of life-history evolution: arrival date in a long-distant migrant. 1057 Frontiers in Ecology and Evolution 9: 78. DOI: 10.3389/fevo.2021.630823.

1058 Tomotani BM, van der Jeugd H, Gienapp P, de la Hera I, Pilzecker J, Teichmann C, Visser ME. 1059 2018. Climate change leads to differential shifts in the timing of annual cycle stages in a 1060 migratory bird. Global Change Biology 24:823-835. DOI: 10.1111/gcb.14006.

1061 Tøttrup AP, Klaassen RHG, Kristensen MW, Strandberg R, Vardanis Y, Lindström Å, Rahbek 1062 C, Alerstam T, Thorup K. 2012. Drought in Africa caused delayed arrival of European 1063 songbirds. Science 338:1307. DOI: 10.1126/science.1227548.

1064 Tøttrup AP, Thorup K, Rahbek C. 2006. Patterns of change in timing of spring migration in 1065 North European songbird populations. Journal of Avian Biology 37:84-92. DOI:

1066 10.1111/j.2006.0908-8857.03391.x.

1067 Tøttrup AP, Thorup K, Rainio K, Yosef R, Lehikoinen E. 2008. Avian migrants adjust migration 1068 in response to environmental conditions en route. Biology Letters 4(6):685-688. DOI:

1069 10.1098/rsbl.2008.0290.

1070 Tøttrup AP, Rainio K, Coppack T, Rahbek C, Thorup K. 2010. Local Temperature Fine-Tunes 1071 the Timing of Spring Migration in Birds. Integrative and Comparative Biology 50 (3): 293-304. 1072 DOI: 10.1093/icb/icq028.

1073 Tryjanowski P, Sparks T H. 2001. Is the detection of the first arrival date of migrating birds 
1074 influenced by population size? A case study of the red-backed shrike Lanius collurio.

1075 International Journal of Biometeorology 45(4): 217-219.

1076 Tryjanowski P, Stenseth NC, Matysioková B. 2013. The Indian Ocean Dipole as an indicator of

1077 climatic conditions affecting European birds. Climate Research 57:45-49. DOI:

$1078 \quad 10.3354 / \mathrm{cr} 01162$.

1079 Tukey J. 1980. We need both exploratory and confirmatory. The American Statistician 34:23-25.

1080 Urban EK, Fry CH, Keith S. 1997. The Birds of Africa. Vol. V. San Diego, London: Academic

1081 Press. Pp: $352-354$.

1082 Underhill LG, Prys-Jones RP, Dowsett RJ, Herroelen P, Johnson DN, Lawn MR, Norman SC,

1083 Pearson DJ, Tree AJ. 1992. The biannual primary moult of Willow Warblers Phylloscopus

1084 trochilus in Europe and Africa. Ibis 134:286-297. DOI: 10.1111/j.1474-919X.1992.tb03811.x.

1085 Usui T, Butchart SHM, Phillimore AB. 2017. Temporal shifts and temperature sensitivity of

1086 avian spring migratory phenology: a phylogenetic meta-analysis. Journal of Animal Ecology

1087 86:250-261. DOI: 10.1111/1365-2656.12612.

1088 Vähätalo AV, Rainio K, Lehikoinen A, Lehikoinen E. 2004. Spring arrival of birds depends on

1089 the North Atlantic Oscillation. Journal of Avian Biology 35:210-216. DOI 10.1111/j.0908-

1090 8857.2004.03199.x.

1091 Valkama J, Saurola P, Lehikoinen A, Lehikoinen E, Piha M, Sola P, Velmala W. 2014. Suomen

1092 Rengastysatlas II. [The Finnish Bird ringing Atlas], Vol. II. Helsinki: Finnish Museum of

1093 Natural History and Ministry of Environment.

1094 Wang G, Schimel D. 2003. Climate change, climate modes, and climate impacts. Annual Review

1095 of Environment and Resources 28(1):1-28. DOI 10.1146/annurev.energy.28.050302.105444

1096 Wood EM, Kellermann JL. 2015. Phenological synchrony and bird migration. Changing

1097 climate and seasonal resources in North America. Cooper Ornithological Society ed. Boca

1098 Raton, London, New York: Taylor \& Francis.

1099 Zaifman J, Shan D, Ay A, Jimenez AG. 2017. Shifts in bird migration timing in North American

1100 long-distance and short-distance migrants are associated with climate change. International

1101 Journal of Zoology 2017: Article ID 6025646. DOI: 10.1155/2017/6025646.

1102 Zhao T, Ilieva M, Larson K., Lundberg M, Neto JM, Sokolovskis K, Åkesson S, Bensch S. 2020.

1103 Autumn migration direction of juvenile willow warblers (Phylloscopus t. trochilus and P. t.

1104 acredula) and their hybrids assessed by qPCR SNP genotyping. Movement ecology 8:22.

Peer] reviewing PDF | (2020:12:56300:3:1:NEW 24 Jan 2022) 
1105 DOI: $10.1186 / \mathrm{s} 40462-020-00209-7$.

1106 Zwarts L, Bijlsma RG, van der Kamp J, Wymenga E. 2009. Living on the Edge: Wetlands and 1107 Birds in a Changing Sahel. Zeist: KNNV Publishing. 


\section{Figure 1}

Approximate migration routes of Willow Warblers that pass through Bukowo and areas influenced by the large-scale climate variables

Symbols of the climate indices and the sources we used to visualise the regions they influence are presented in Table 1. The ranges of months are the main periods when Willow Warblers occur within their breeding, migration and wintering areas. The westernmost route in the Sahel region reflects geolocator tracks of birds breeding in Denmark (Lerche-Jørgensen et al. 2017), the eastern route considers genotyping (Zhao et al., 2020). This figure is based on Remisiewicz \& Underhill (2020, modified), and is derived from " Phylloscopus trochilus Range Map.png " by Keith W. Larson, licensed under CC-BY-SA-3.0 by Magdalena Remisiewicz. 


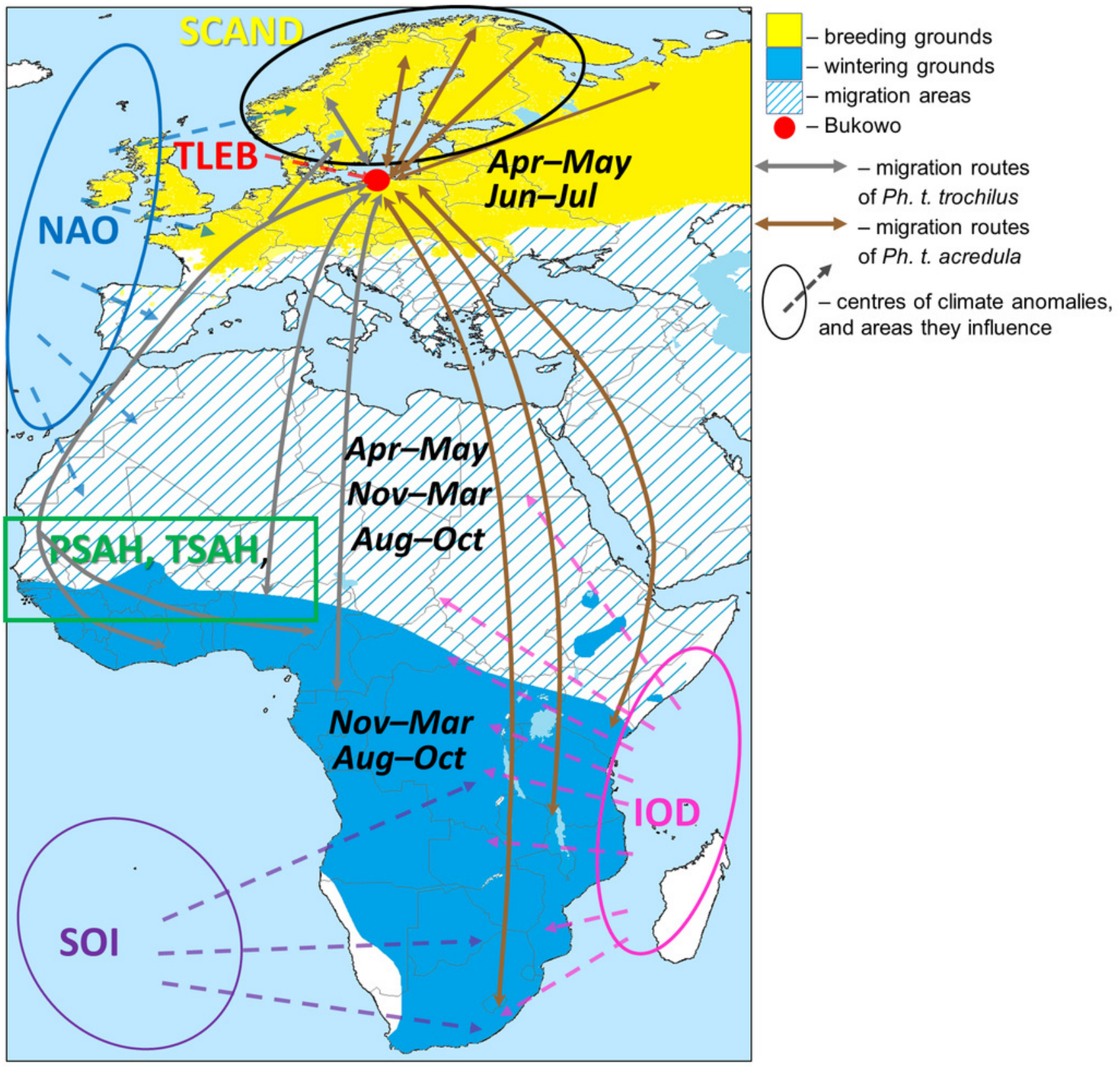




\section{Figure 2}

Division of the overall spring migration curve into thirds of average passage 1982-2017 and the division of Annual Anomaly (AA) for 2012 into three main periods using the derived ranges of dates

(A) Division of the multiyear average migration curve into three non-overlapping main periods of spring (MP1, MP2, MP3). Red line $=1982-2017$ average migration curve, black lines $=$ division into thirds of average passage. (B) Ranges of dates from Fig. $2 \mathrm{~A}$ to decompose AA for 2012 into three periods. Blue line = migration curve for 2012. The areas in the three main periods (blue and white patterns), total to overall AA for 2012. MP1 = main period $1, M P 2=$ main period $2, M P 3=$ main period 3 ; ranges of percentiles and symbols of periods as in Table 2. 

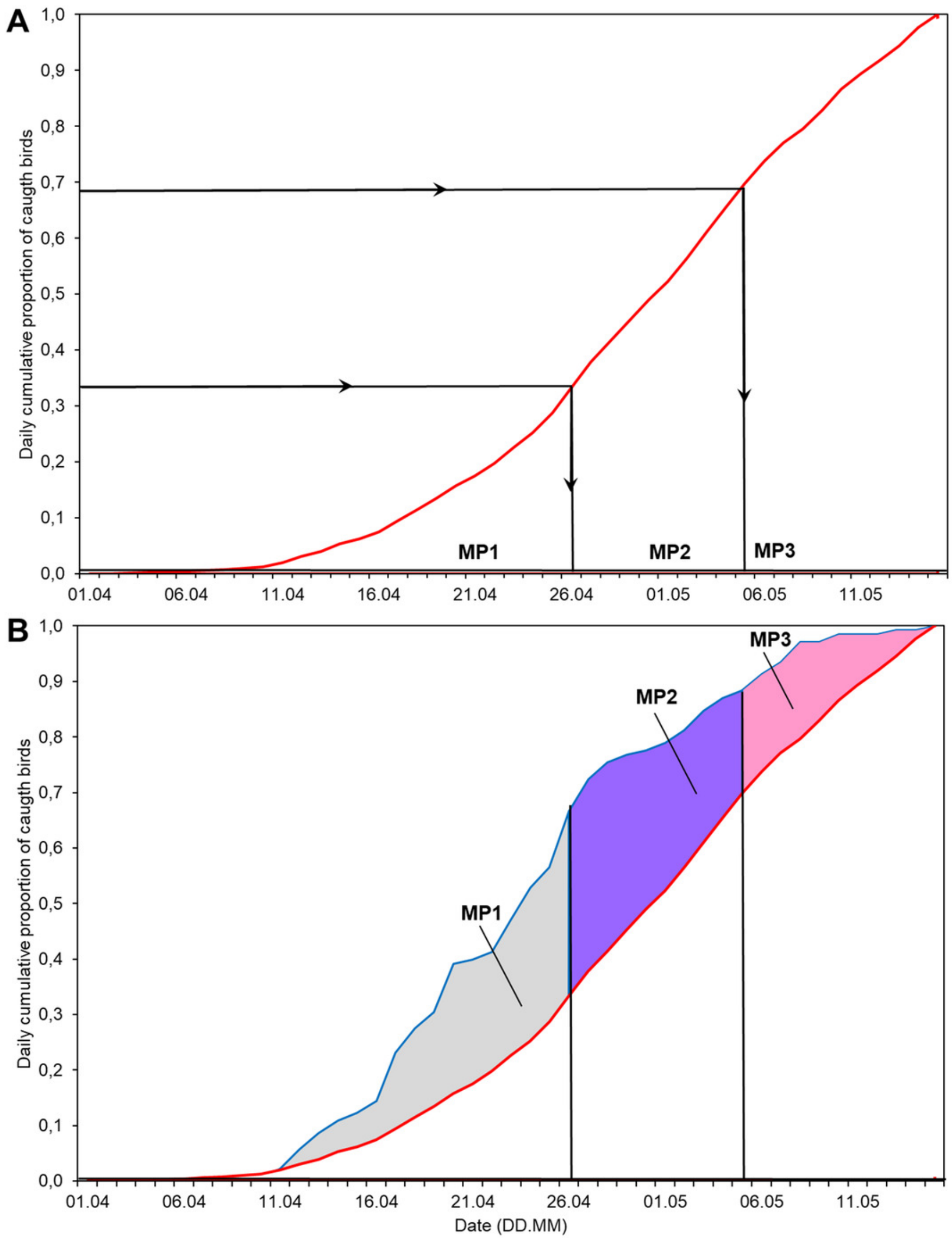
Figure 3

Trends for the Annual Anomaly in three main periods (A-C) and the whole season (D) for Willow Warbler spring migration at Bukowo, Poland, 1982-2017.

Symbols of spring periods as in Table 2 and Fig. 2 ; ** $-p$ significant after Benjamini-Hochberg correction for multiple comparisons. More statistics for regression equations in Table S7.
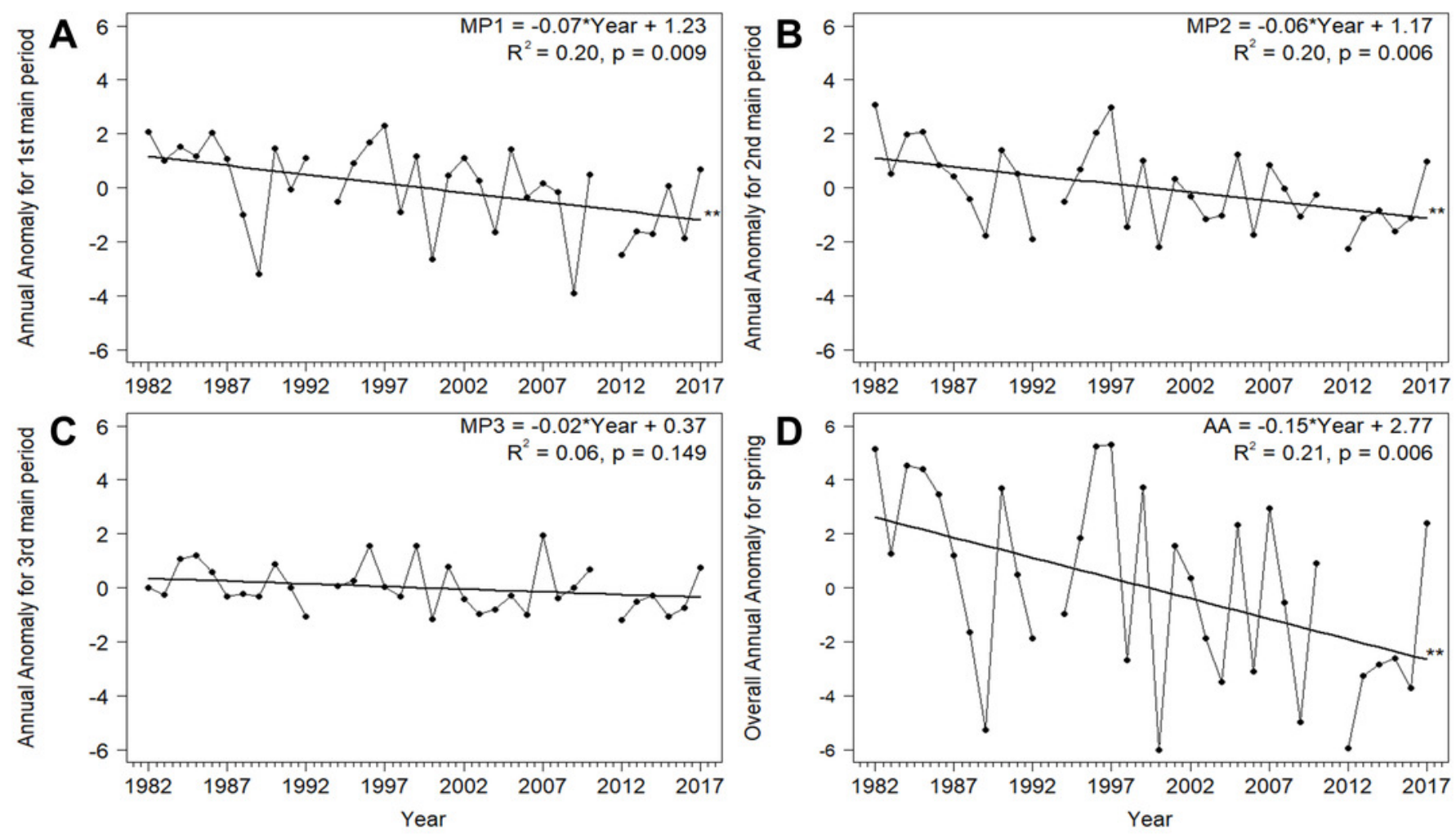


\section{Figure 4}

Partial correlation coefficients for AA in nine overlapping sub-periods of spring against the nine main climate indices for Willow Warbler spring migration at Bukowo, Poland, 1982-2017.

The signs of partial correlation coefficients (Table S14) were inverted, so the positive values at $\mathrm{Y}$-axis indicate negative correlation to better visualise their changes with the progress of migration; source data in Table S15. Symbols of climate indices in Table 1, symbols of spring sub-periods in Table 2 . 

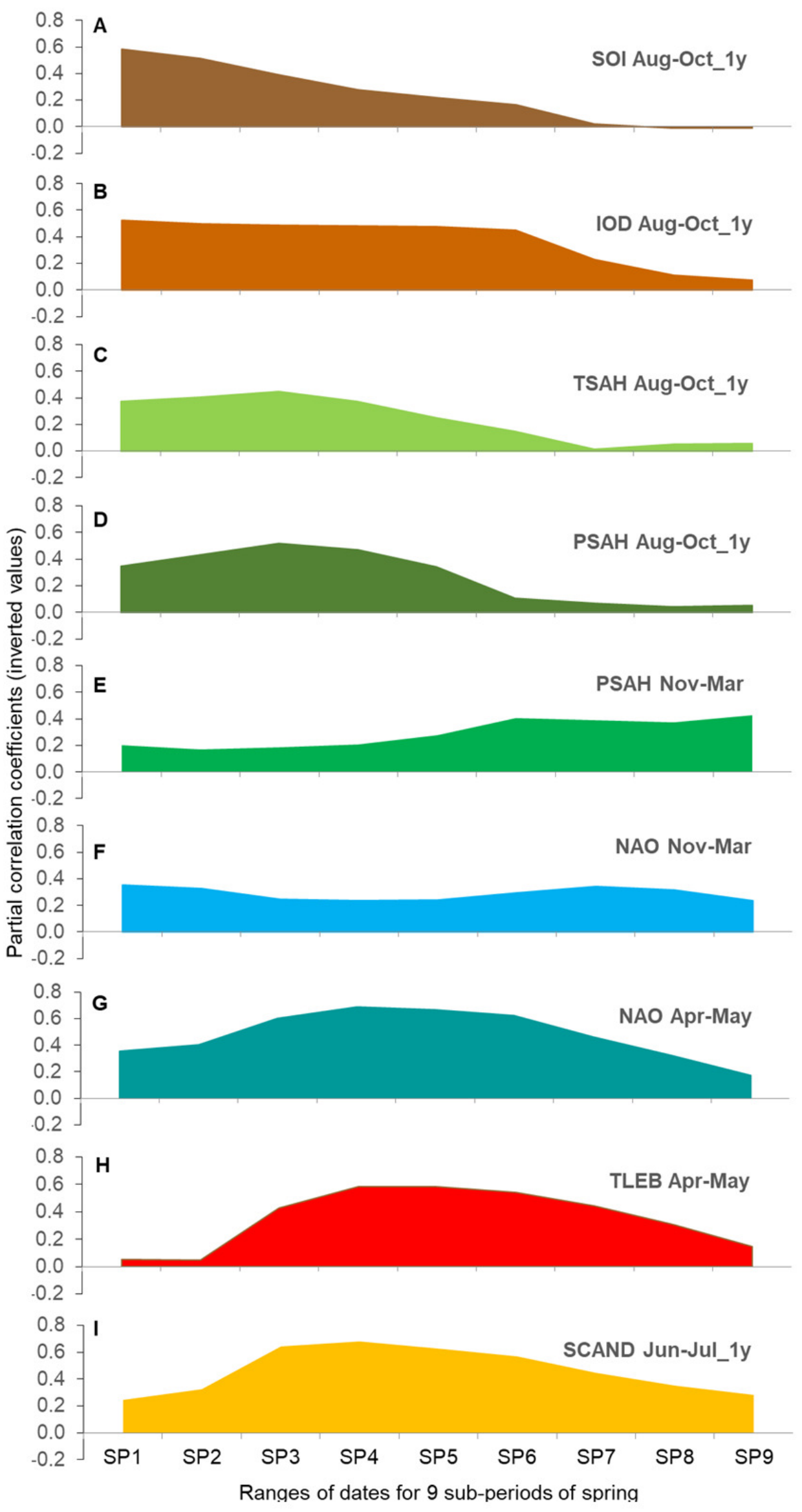


\section{Figure 5}

Relationships between AA in three main periods $(A-C)$ and the whole season (D) of Willow Warbler spring migration in 1982-2017 and the count of juveniles caught the previous autumn at Bukowo, Poland.

White circle $=$ the outlier value in autumn 1982 excluded from the regression. ${ }^{* *}-p$ significant after Benjamini-Hochberg correction for multiple comparisons. Details of regressions in Table S16. 

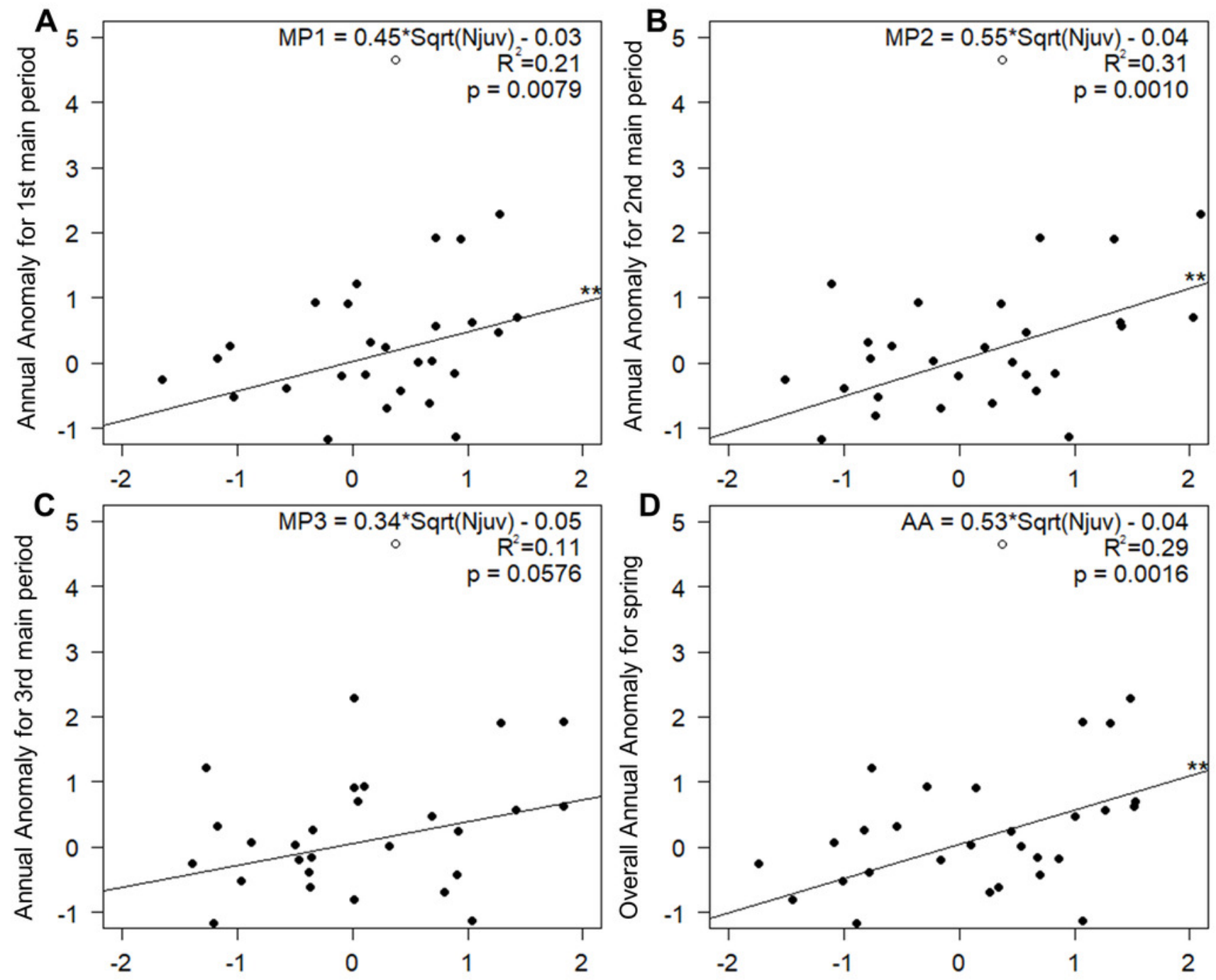

Standardised Sqrt of Njuv the previous autumn

Standardised Sqrt of Njuv the previous autumn 


\section{Table $\mathbf{1}$ (on next page)}

Explanatory variables used in modelling Willow Warbler spring migration (1 April-15 May) over 1982-2017 at Bukowo, Poland.

The nine main climate indices used in the second step of analyses are marked in bold face. 


\begin{tabular}{|c|c|c|c|}
\hline No & $\begin{array}{l}\text { Symbols used } \\
\text { in the text }\end{array}$ & Explanatory variable & Source, key references \\
\hline 1 & TLEB APR-MAY & $\begin{array}{l}\text { Apr-May mean of daily means of local } \\
\text { temperatures in Łeba }\end{array}$ & http://www.ecad.eu \\
\hline 2 & NAO APR-MAY & $\begin{array}{l}\text { Apr-May mean of Northern Atlantic } \\
\text { Oscillation Index }\end{array}$ & $\begin{array}{l}\text { http://www.cpc.ncep.noaa.gov/ } \\
\text { Hurrell, } 1995\end{array}$ \\
\hline 3 & SCAND APR-MAY & Apr-May mean of Scandinavian Index & $\frac{\text { http://www.cpc.ncep.noaa.gov/ }}{\text { Bueh \& Nakamura, } 2007}$ \\
\hline 4 & NAO NOV-MAR & $\begin{array}{l}\text { Nov-Mar mean of Northern Atlantic } \\
\text { Oscillation Index }\end{array}$ & http://www.cpc.ncep.noaa.gov/ \\
\hline 5 & PSAH NOV-MAR & $\begin{array}{l}\text { Nov-Mar mean of Sahel Precipitation Index } \\
\text { within } 10^{\circ}-20^{\circ} \mathrm{N}, 20^{\circ} \mathrm{W}-10^{\circ} \mathrm{E}\end{array}$ & $\frac{\text { http://research.jisao.washington.edu/ }}{\text { data/sahel//sahelprecip19012017 }}$ \\
\hline 6 & TSAH NOV-MAR & $\begin{array}{l}\text { Nov-Mar mean of Sahel temperature } \\
\text { anomaly within } 10^{\circ}-20^{\circ} \mathrm{N}, 20^{\circ} \mathrm{W}-10^{\circ} \mathrm{E}\end{array}$ & http://climexp.knmi.nl \\
\hline 7 & IOD NOV-MAR & Nov-Mar mean of Indian Ocean Dipole & $\begin{array}{l}\text { https://psl.noaa.gov/gcos_wgsp/ } \\
\text { Timeseries }\end{array}$ \\
\hline 8 & SOI NOV-MAR & Nov-Mar mean of Southern Oscillation Index & $\begin{array}{l}\text { http://www.cpc.ncep.noaa.gov/ } \\
\text { Richard et al., } 2001\end{array}$ \\
\hline 9 & NAO AUG-OCT_1y & $\begin{array}{l}\text { Aug-Oct mean of previous year's Northern } \\
\text { Atlantic Oscillation Index }\end{array}$ & $\begin{array}{l}\text { http://www.cpc.ncep.noaa.gov/ } \\
\text { Hurrell, } 1995\end{array}$ \\
\hline 10 & PSAH AUG-OCT_1y & $\begin{array}{l}\text { Aug-Oct mean of previous year's Sahel } \\
\text { Precipitation Index }\end{array}$ & $\begin{array}{l}\text { http://research.jisao.washington.edu/ } \\
\text { data/sahel//sahelprecip19012017 }\end{array}$ \\
\hline 11 & TSAH AUG-OCT_1y & $\begin{array}{l}\text { Aug-Oct mean mean of previous year's } \\
\text { Sahel temperature anomaly within } 10^{\circ}-20^{\circ} \mathrm{N} \text {, } \\
20^{\circ} \mathrm{W}-10^{\circ} \mathrm{E}\end{array}$ & $\begin{array}{l}\text { http://climexp.knmi.nl } \\
\text { ERA5 dataset }\end{array}$ \\
\hline 12 & IOD AUG-OCT_1y & $\begin{array}{l}\text { Aug-Oct mean of previous year's Indian } \\
\text { Ocean Dipole }\end{array}$ & $\begin{array}{l}\text { https://psl.noaa.gov/gcos_wgsp/Tim } \\
\text { eseries; } \\
\text { Marchant et al., } 2006\end{array}$ \\
\hline 13 & SOI AUG-OCT_1y & $\begin{array}{l}\text { Aug-Oct mean of previous year's Southern } \\
\text { Oscillation Index }\end{array}$ & $\begin{array}{l}\text { http://www.cpc.ncep.noaa.gov/ } \\
\text { Richard et al., } 2001\end{array}$ \\
\hline 14 & NAO JUN-JUL_1y & $\begin{array}{l}\text { Jun-Jul mean of previous year's Northern } \\
\text { Atlantic Oscillation Index }\end{array}$ & $\begin{array}{l}\text { http://www.cpc.ncep.noaa.gov/ } \\
\text { Hurrell, } 1995\end{array}$ \\
\hline 15 & SCAND JUN-JUL_1y & $\begin{array}{l}\text { Jun-Jul mean of previous year's } \\
\text { Scandinavian Index }\end{array}$ & $\frac{\text { http://www.cpc.ncep.noaa.gov/ }}{\text { Bueh \& Nakamura, } 2007}$ \\
\hline 16 & Year & Year as a number; $1982=$ Year 1 & Our database \\
\hline
\end{tabular}




\section{Table 2 (on next page)}

Sections of the Annual Anomaly $(A A)$ for main periods and sub-periods of spring, and for the whole spring, used as response variables in modelling Willow Warbler spring migration (1 April-15 May) in 1982-2017 at Bukowo, Poland.

Percentiles $=$ the ranges of percentiles at multiyear curve used to derive the ranges of dates used to distinguish main periods (MP) and sub-periods (SP) of AA (Fig. 2). Three main nonoverlapping periods of spring are marked in bold face. 


\begin{tabular}{llll}
\hline No & $\begin{array}{l}\text { Symbol used } \\
\text { in the text }\end{array}$ & Percentiles & Response variable \\
\hline 0 & AA & $0-100 \%$ & Annual Anomaly for 1 April-15 May \\
\hline $\mathbf{1}$ & MP1 & $\mathbf{0 - 3 3 \%}$ & Annual Anomaly for 1-26 April \\
$\mathbf{2}$ & MP2 & $\mathbf{3 4 - 6 6 \%}$ & Annual Anomaly for 27April-5 May \\
$\mathbf{3}$ & MP3 & $\mathbf{6 7 - 1 0 0 \%}$ & Annual Anomaly for 6-15 May \\
\hline 1 & SP1 & $0-20 \%$ & Annual Anomaly for 1-22 April \\
2 & SP2 & $11-30 \%$ & Annual Anomaly for 18-25 April \\
3 & SP3 & $21-40 \%$ & Annual Anomaly for 24-28 April \\
4 & SP4 & $31-50 \%$ & Annual Anomaly for 26 April-1 May \\
5 & SP5 & $41-60 \%$ & Annual Anomaly for 29 April -3 May \\
6 & SP6 & $51-70 \%$ & Annual Anomaly for 2-5 May \\
7 & SP7 & $61-80 \%$ & Annual Anomaly for 4-7 May \\
8 & SP8 & $71-90 \%$ & Annual Anomaly for 6-11 May \\
9 & SP9 & $81-100 \%$ & Annual Anomaly for 9-15 May \\
\hline
\end{tabular}




\section{Table 3 (on next page)}

Relationship between climate variables and Annual Anomalies for the three main periods of spring, and for whole season of Willow Warbler spring migration at Bukowo, Poland, in 1982-2017.

Estimate - coefficients from multiple regression, SE - standard error, $t, p-t$-test and significance of each estimate, $p<0.05$ in bold face. VIF - variance inflation factor, $R^{2}$ partial determination coefficient for each factor, $p R$ - partial correlation coefficient.

Abbreviations of climate variables as in Table 1, symbols of explanatory variables as in Table 2. Full models presented in Table S8, model selection presented in Tables S9-S12. 


\begin{tabular}{|c|c|c|c|c|c|c|c|}
\hline $\begin{array}{l}\text { Explanatory } \\
\text { variable }\end{array}$ & Estimate & SE & $t$ & $p$ & VIF & $R^{2}$ & $p R$ \\
\hline MP1 & \multicolumn{7}{|c|}{ Best model statistics: $\mathrm{F}_{6,28}=8.23, \mathrm{AdjR}^{2}=56.6 \%$} \\
\hline NAO APR-MAY & -0.39 & 0.12 & -3.20 & 0.003 & 1.12 & 0.27 & -0.52 \\
\hline SOI NOV-MAR & -0.46 & 0.13 & -3.48 & 0.002 & 1.37 & 0.30 & -0.55 \\
\hline IOD AUG-OCT_1y & -0.44 & 0.14 & -3.04 & 0.005 & 1.63 & 0.25 & -0.50 \\
\hline PSAH AUG-OCT_1y & -0.39 & 0.13 & -2.94 & 0.007 & 1.38 & 0.24 & -0.49 \\
\hline TSAH AUG-OC & -0.31 & 0.12 & -2.46 & 0.020 & 1.22 & 0.18 & -0.42 \\
\hline SCAND JUN-JUL_1y & -0.27 & 0.13 & -2.13 & 0.042 & 1.22 & 0.14 & -0.37 \\
\hline MP2 & \multicolumn{7}{|c|}{ Best model statistics: $\mathrm{F}_{5,29}=14.42, \mathrm{AdjR}^{2}=66.4 \%$} \\
\hline TLEB APR-MAY & -0.48 & 0.11 & -4.22 & 0.000 & 1.28 & 0.38 & -0.62 \\
\hline $\mathrm{NAOA}$ & -0.48 & 0.10 & -4.70 & 0.000 & 1.06 & 0.43 & -0.66 \\
\hline IOD AL & -0.32 & 0.11 & -2 & 0.007 & 1.20 & 0.23 & -0.48 \\
\hline PSAH AUG-OCT_1y & -0.24 & 0.11 & -2.26 & 0.032 & 1.18 & 0.15 & -0.39 \\
\hline SCAND JUN-JUL_1y & -0.51 & 0.11 & -4.52 & 0.000 & 1.31 & 0.41 & -0.64 \\
\hline MP3 & \multicolumn{7}{|c|}{ Best model statistics: $\mathrm{F}_{5,29}=4.01, \mathrm{AdjR}^{2}=30.7 \%$} \\
\hline TLEB APR-MAY & -0.33 & 0.16 & -2.14 & 0.041 & 1.20 & 0.14 & -0.37 \\
\hline NAO APR-MAY & -0.25 & 0.15 & -1.70 & 0.100 & 1.06 & 0.09 & -0.30 \\
\hline NAO NOV-MAR & -0.30 & 0.15 & -2.05 & 0.050 & 1.04 & 0.13 & -0.36 \\
\hline PSAH NOV-MAR & -0.35 & 0.15 & -2.41 & 0.022 & 1.06 & 0.17 & -0.41 \\
\hline SCAND JUN-JUL_1y & -0.41 & 0.16 & -2.54 & 0.017 & 1.26 & 0.18 & -0.43 \\
\hline AA & \multicolumn{7}{|c|}{ Best model statistics: $\mathrm{F}_{7,27}=8.09, \mathrm{AdjR}^{2}=59.4 \%$} \\
\hline TLEB APR-MAY & -0.31 & 0.13 & -2.39 & 0.024 & 1.38 & 0.17 & -0.42 \\
\hline NAO APR-MAY & -0.38 & 0.12 & -3.31 & 0.003 & 1.12 & 0.29 & -0.54 \\
\hline NAO NOV-MAR & -0.45 & 0.14 & -3.22 & 0.003 & 1.65 & 0.28 & -0.53 \\
\hline TSAH NOV-MAR & -0.35 & 0.15 & -2.40 & 0.023 & 1.70 & 0.18 & -0.42 \\
\hline SOI AUG-OCT_1y & -0.37 & 0.14 & -2.54 & 0.017 & 1.75 & 0.19 & -0.44 \\
\hline IOD AUG-OCT_1y & -0.49 & 0.15 & -3.27 & 0.003 & 1.86 & 0.28 & -0.53 \\
\hline SCAND JUN-JUL_1y & -0.33 & 0.13 & -2.58 & 0.016 & 1.38 & 0.20 & -0.44 \\
\hline
\end{tabular}

